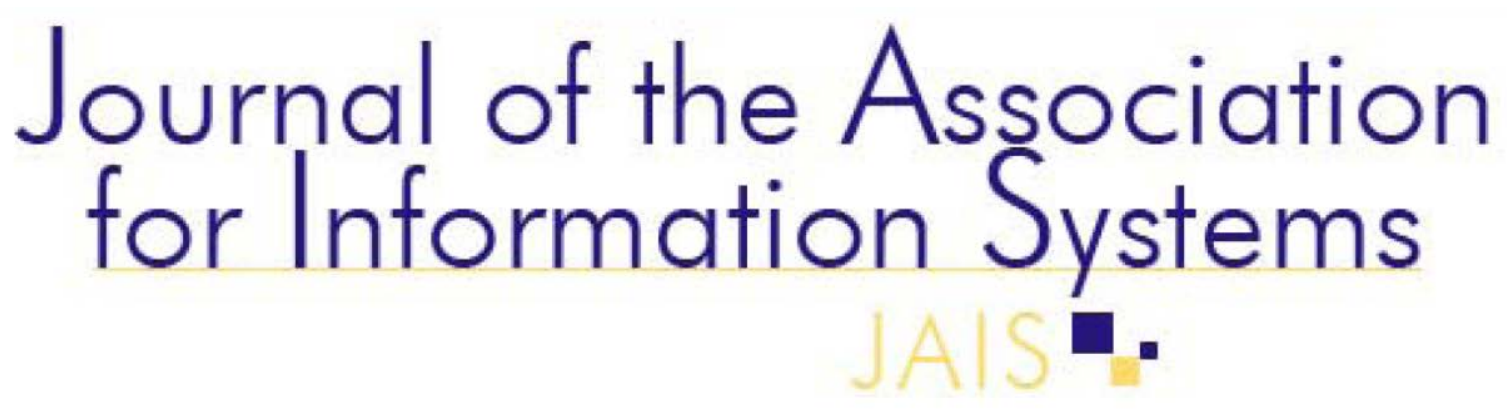

Research Article

\title{
Rethinking Lurking: Invisible Leading and Following in a Knowledge Transfer Ec osystem
}

\author{
Jocelyn Cranefield \\ Vic toria University of Wellington \\ jocelyn.cranefield@vuw.ac.nz \\ Pak Yoong \\ Vic toria University of Wellington \\ pak.yoong@vuw.ac.nz
}

\author{
Sid L Huff \\ Vic toria University of Wellington \\ sidhuff99@gmail.com
}

\begin{abstract}
The tem lurker connotes a low-value role in online communities. Despite making up the majority of members, these invisible individuals are often cast as peripheral players who should be encouraged to participate more fully. We argue that the lurker concept is problematic and that online communities, and the roles associated with them, need to be reconceptualized. We report on a study of online communities in a New Zealand professional development program. We found that two knowledge broker types played key roles in transfeming knowledge: connector-leaders, who had a strong online presence, and follower-feeders, who communicated largely invisibly, via side-channels. Despite their different online profiles, both brokers used "lurking" pumposively to perform two sets of invisible online activities: managing the knowledge agenda, and mentoring/being mentored. These activities supported their roles as leaders and followers, and sustained a symbiotic relationship. Decisions to "lurk" arose from the need for these brokers to negotiate diverse boundaries: the boundaries of micro-culture associated with communication contexts, the theory-practice boundary, role boundaries, and the online-offline boundary. Combining the concept of polycontextuality with boundary spanning theory, we propose an altemative way of understanding both lurking and online communities: the three-tier knowledge transfer ecosystem (KTE), a system of engagement spaces comprising diverse online and offline contexts in which individuals make continual decisions to cross between less- or more-visible settings. The study illustrates how key phenomena may remain invisible without a shift in level of analysis, and how using an anachronistic concept to frame a study can unintentionally constra in its value.
\end{abstract}

Keywords: Networks and Communities, Collaboration, Community Wide Systems, Interpretive, Ca se Study.

* Remko Helms was the accepting senior editor. This a rticle was submitted on $7^{\text {th }}$ August 2011 a nd went through four revisions.

Volume 16, Issue 4, pp. 213-247, April 2015 


\section{Rethinking Lurking: Invisible Leading and Following in a Knowledge Transfer Ecosystem}

\section{Introduction}

Invisible members of online communities-those who access, but do not contribute to, shared online spaces-have traditionally been conceived of as inactive, peripheral, and non-productive participants. The term lurker, when used to describe such individuals, typically connotes a low-value, marginal role that is characterized by a reluctance, or lack of readiness, to contribute. Although it is thought that lurkers make up the vast majority of many online communities, we have limited understanding of what value these individuals provide, or, indeed, whether they provide any value at all. We argue that the concept of the lurker is problematic, and that profound changes in the manifestation of online communities since they were first studied in the 1990s make it necessary to reconceptualize not only community roles, but also the nature of the online community itself.

This paper builds on an interpretive study that sought to understand how knowledge transfer was facilitated by online communities in a three-year ICT professional development program for New Zealand teachers. As part of this study, we sought to identify and understand the nature of key roles involved in knowledge transfer. Our interest in lurking arose from examining the activities of a subset of participants whose profiles appeared to fit the lurker stereotype, yet whose invisible online activities proved critical to their roles as knowledge brokers. We subsequently recognized that lurking was employed purposively, not only by this group, but also by a more prominent group of knowledge brokers whose online profiles did not fit the lurker stereotype. Our insights about the significance of lurking in this case did not arise immediately, but came about as a result of a conscious decision to elevate the level of analysis of our study as we came to understand the complex, overlapping nature of the communities involved and view them as part of a larger system.

The paper is structured as follows: In Section 2, we provide an overview of the research on the lurker role, the lurker's perceived impact in online communities, and associated issues. We outline limitations of the lurker concept in which we draw particular attention to recent changes in the pervasiveness and embeddedness of technology, the rapid diffusion of Web 2.0 tools and social networking technologies, and the nature of what constitutes an online community. Despite online communities' increasing multimodality, complexity, and overlapping nature, and the increased frequency and ubiquity of online communication arising from mobility, the online community concept has remained relatively stable in studies, in which it has effectively acted as a constraint on the phenomena and research issues that researchers view as relevant. We argue that it is timely to reconceptualize not only the lurker role, but also the concept with which we frame such studies. In Section 3, we then outline the study design and method, before reporting in detail in Section 4 on the results of the research project. In Section 5, building on these results, we combine the concept of polycontextuality with boundary spanning theory to propose an alternative way of conceptualizing online communities and roles. We argue that the online community is best seen as part of a larger, polycentric and polycontextual system: the knowledge transfer ecosystem (KTE), which comprises a multiplicity of engagement spaces-visible and invisible online communication contexts and offline communication settings-in and across which individuals interact. We also argue that the nature of value of roles in this ecosystem is best understood by focusing on the activities that occur across KTE boundaries. The significance (if any) of a contextual behaviour such as lurking can only be understood by exploring its precursors and consequences in the larger system. In Section 6, we conclude the paper by discussing the implications of this study for online community stakeholders and for the wider IS field.

\section{Literature Review}

\subsection{The Lurker}

A lurker is an invisible participant, someone who may read and access community content but who does not visibly contribute to the shared online spaces of an online community to which they belong. While studies are aligned in characterizing the lurker as an inactive or silent participant (Leshed, 2005), exact definitions of the lurker role vary (Wang \& Yu, 2012). Preece, Nonnecke, and Andrews 
(2004) define a lurker as someone who has never posted, while others include infrequent posters (e.g., Ridings, Gefen, \& Arinze, 2006; Chen \& Chang, 2011), and/or those who have not posted recently (Nonnecke, 2000; Nonnecke \& Preece, 2000). Historically, lurking has been researched largely in relation to community email lists, chat rooms, and discussion boards (Dennen, 2008). The lurking phenomenon has long been regarded as an enigma that must be better understood. This is because lurkers are believed to form the vast majority of many online communities, by which they constitute a silent, or invisible, key stakeholder group (Jones \& Rafaeli, 1999; Nielsen, 2006; Nonnecke \& Preece, 2000), yet the survival of online communities is dependent on ongoing participation in terms of both knowledge seeking and knowledge contribution (Phang, Kankanhalli, \& Sabherwal, 2009). Despite a perennial concern about how to promote increased participation, there has been an over-representation of studies about the behaviour of more-visible or active online community members (Rafaeli, Ravid, \& Soroka, 2004). This no doubt reflects a fundamental problem that has confronted researchers: information about lurker behavior is notably absent from what Ridings et al. (2006) describe as "the obvious community data source, the postings" (p. 329).

In the early days of online communities, researchers took a dim view of lurkers (Preece et al., 2004): they considered active posters to be the only legitimate community members (Beaudouin \& Velkovska, 1999; Parks \& Floyd, 1996). Lurkers were once even seen as posing a problem for contributing members. Kollock and Smith (1996) characterize non-active Usenet participants as free riders who wasted valuable bandwidth while exploiting the collective goods produced by others (p. 9). However, together with advances in Internet speed and bandwidth, the tide of opinion turned, and demographic studies revealed that the majority of many online communities were lurkers (Jones \& Rafaeli, 1999; Nonnecke \& Preece, 2000; Whittaker et al., 1998). This, together with the accelerating uptake of online communities and the Internet, made it imperative to better understand lurking.

Although the free-rider characterization continues to appear ${ }^{1}$, the negative view of the lurker has largely been superseded by a more positive view. Researchers have revealed that lurkers may identify as community members (Nonnecke \& Preece, 1999), that they may be accepted as such by active online members (Preece et al., 2004), and that they may learn vicariously through engaging with and reflecting on others' contributions (e.g., Arnold \& Paulus, 2010; Beaudoin, 2002; Waters \& Gasson, 2006). In light of such emerging understandings, Nonnecke (2000) has advocated for use of the term non-public participant. However, the catchy lurker label, with its pejorative undertones, appears to have stuck.

Studies have, nonetheless, begun to reframe lurking as a complex set of behaviours or sub-roles rather than a singular phenomenon. Leshed (2005) proposes a participation model with two dimensionsintensity and publicity - to acknowledge the complexity of online participation, while others identify diverse lurker sub-categories. For example, Dennen (2008) suggests that "pure" lurking exists at one end of the participation continuum, "with many users engaged in behavior that is a continuum of posting and reading" (p. 1627). Similarly, Wang and Yu (2012) propose a continuum model in which the trouble maker, lurker, non-contributing participant, partial-contributing participant, and participant provide different degrees of value to the community. In an e-learning setting, Egan, Jefferies, and Johal (2006) differentiate lurkers from shirkers (those who never log in), while Chen and Chang (2011) identify three categories of "relatively silent" lurkers: they compare the frequency of their posts and their online presence (time spent logged in) to community averages. Analyzing the posts of each lurker group with Waters and Gasson's (2006) learner role behaviors, Chen and Chang found that lurkers with a high online presence contributed as many high-value posts as ordinary members, which illustrated their familiarity with prior discussion and their role in co-constructing knowledge.

Several recent studies focus on lurkers' cognitions, motivations, and/or beliefs (Bishop, 2007; Kucuk, 2010; Nonnecke, Preece, Andrews, \& Voutour, 2004; Soroka \& Rafaeli, 2006). These studies are primarily concerned with how to facilitate "delurking" (the conversion of lurkers to non-

${ }^{1}$ For example, we can see in analyses of electronic networks of practice by Wasko and Faraj (2005) and Wasko, Teigland, and Faraj (2009) and in a classification of user types by Wang and Yu (2012) in which the lurker who consumes without contributing is seen as generating a zero value. 
lurkers) or novices (Bishop, 2007) (which is seen as necessary to ensure a community's survival). Soroka and Rafaeli (2006) conclude that triggers of active online participation arise from both situational and dispositional factors, while Ridings et al. (2006) and Kucuk (2010) expose psychological barriers to posting, such as lack of trust. Bishop (2007) has proposed a multi-level ecological cognition framework for understanding online participation and suggests that providers should promote conversion by challenging lurker beliefs about the value of contributing. Like much research into online communities, these studies present a mono-centric view of the locus of the community: they focus mainly on participant behavior in relationship to the online setting of central concern; what Ridings et al. (2006, p. 329) term the obvious community data source. They can also be seen as taking a situated learning perspective. Situated learning theory, developed by Lave and Wenger (1991) in a study of apprenticeships in face-to-face workplaces, explains the process of becoming a member of a community of practice as being a gradual movement from the periphery of practice (legitimate peripheral participation) toward the center as one develops a stronger, more knowledgeable community identity. However, the transferability of Lave and Wenger's (1991) theory to an online setting is questionable: the question that arises is, where should we see the lurker as being situated?

Lurking is now known to be a fundamentally contextual activity-a participant may lurk in one community setting while actively posting in another (Nonnecke \& Preece, 1999; Chen, Chang, \& Wang, 2010). Despite this and Kollock and Smith's (1996) suggestion that online community members may have "a multitude of back-channels of communication that often escape our examination" (p. 5), there is little research that considers how lurkers engage in cross-community participation and/or how they interact with others via online back-channels such as email. Exceptions include Beaudoin's (2002) survey in which participants alluded to the frequent use of email, and Chen et al.'s (2010) identification of a subset of students who lurked in a cross-group forum and delivered material from this forum back to their own workgroup forums. These studies suggest that, in some cases, there may be meaningful roles associated with the lurker's multi-situated existence. Perhaps more significantly, studies rarely consider what the online lurker might be doing in the offline world, and how this might relate to lurkers' online behaviors and experiences. An exception is a study by Takahashi, Fujimoto, and Yamasaki (2003) that investigates lurkers' influence outside online communities. The authors identify a new category of lurker, the active lurker, who transfers knowledge gained from lurking in the outside world. Takahashi et al. subdivide the active lurker into two subcategories: the active lurker as propagator-someone who propagates information or knowledge they have gained online to others, and the active lurker as practitioner-someone who uses this information in their own, or their organization's, activities (p. 2). The potential for further research in this line is also highlighted by Arnold and Paulus (2010), who report on vicarious learning that occurred among inactive users of the social networking site Ning. The authors conclude that "this calls into question our reliance on visible online behaviours as evidence for what happens in online environments" (p. 195).

\subsection{The Need for a Reconceptualization of the Lurker}

Studies such as those by Takahashi et al. (2003) and Arnold and Paulus (2010) suggest that focusing on lurking per se-based around studying a community discussion space from which the lurker's voice is absent-may not be the best way to understand the activity and value of invisible community participants. The absence of discernable behaviour in the data record of interest may be a strong indicator that more valuable information would be gained by looking elsewhere. Also, as Gleave, Welser, Lento, and Smith (2009) point out, if a behavioral pattern initially stands out in an online community setting (in this case lurking), this does not necessarily mean that the behavior has particular social significance (p. 3). It follows that the label lurker should not be confused with a meaningful social role. Building on Stryker's symbolic interactionist identity theory, Gleave et al. (2009) argue that social roles in online communities should be identified not only based on behavioral regularities, but also on relational patterns (the ways in which particular individuals interact with others in the community at a structural level ${ }^{2}$ ). It appears that the relational dimension of the role is absent from the lurker literature, which signals an opportunity for research. The above issues,

\footnotetext{
${ }^{2}$ The authors use ego analysis to identify role-related structural signatures
} 
together with our currently limited understanding about lurking, demonstrate that research into the nature of roles in online communities is still at an early stage of maturity. This is particularly so when it comes to understanding the roles and behaviors that occur among the invisible majority. In Section 2.3, we outline how substantial recent changes in the manifestation of the online community have fundamentally altered the context for community interactions, which has made it both necessary and timely to reconceptualize the traditional online community concept.

\subsection{The Changing Nature of the Online Community}

The term online community has become widely used as an "in term" (i.e., fashionable) to describe almost any group of people who use Internet technologies to communicate (Preece \& MaloneyKrichmar, 2006). While recognizing that what constitutes a community in an online setting is a source of debate, we follow those who take an operational, socio-technological view, and define an online community as a group of people who communicate and interact in a computer-supported virtual space for a particular purpose, guided by community "policies" (norms and rules), and supported by software (de Souza \& Preece, 2004; Preece, 2000; Phang et al., 2009). Unlike members of a fully virtual community, members of an online community may also meet face-to-face (Dubé, Bourhis, \& Jacob, 2006). Since the first wave of studies into online communities conducted in the late 20th century, there have been radical changes in the range and pervasiveness of online communication technologies, and the ways and extent with which such tools are used. The advent and rapid uptake of Web 2.0 tools has given individuals an unprecedented degree of control over self-publishing, while the growing array of social networking technologies, combined with the advances in usability that have accompanied the rise of mobile devices and applications, have made it easy to participate in a world of extraordinary inter-connectedness; indeed, it is difficult for us to escape from this hyperconnected world. This paradigm shift, which has occurred over a mere two decades, has been accompanied by fundamental changes in the nature of what constitutes an online community.

Early research into online communities, conducted in bounded online spaces such as discussion groups and facilitated forums, made it easy to distinguish a community from a network. However, more-recent studies conducted in Web 2.0 settings challenge the nature of this distinction. For example, Efimova and Hendrik (2005), Hodkinson (2004), Wei (2004) and Kaiser, Müller-Seitz, Pereira Lopes, and Pina e Cunha (2007) have identified online communities in the high-density areas of reciprocal connections in blogging networks. In these communities, discussions are neither bounded nor facilitated, but distributed among the blogs of members who employ practices such as tagging, RSS feeding, and social bookmarking to monitor the conversation. As the use of diverse electronically mediated social contexts (EMSCs) becomes increasingly prevalent in social and business environments (Vaast \& Walsham, 2013), freely available tools such as wikis, blogs, social bookmarking tools, and diverse social networking services provide a range of peer-to-peer communication contexts that co-exist with traditional closed community platforms such as discussion forums. As Preece and Maloney-Krichmar (2006) note, communication among online community members today is rarely restricted to a single medium, and the traditional online community is effectively a legacy concept.

\subsection{Re-conceptualising the Online Community}

Despite the trends we outline above, relatively few studies seem to have tackled the changing sociotechnological reality, and research continues to frame online communities as stand-alone entities (e.g., Ransbotham \& Kane, 2011; Jin, Park, \& Kim, 2010). The issue does not lie in the quality of this research, but in the limitations that its framing creates and perpetuates in terms of what researchers see as relevant: if an online community is seen by default as having a mono-centric, platform-based locus of activity, then activity outside of that locus is easily seen as irrelevant. The traditional monocentric view of the online community risks constraining the potential for researchers to develop morecomplex insights about the flow of knowledge in and across communities-and even to ask the questions that would lead to such insights.

An alternative view is found in the work of Castro $(2004,2006)$, who argues that, with so many open communication channels, today's online communities should be seen as operating in a "universal 
theatre" (2004, p. 6). He proposes an ecosystem model of an open conversation space in which an individual may participate as a core member in some communities and in a peripheral way in others. The ecosystem is made up of overlapping communities containing groups of people who have a shared practice or interest and their conversations. In the ecosystem, "information gathered in one place... may have an echo and reflection in several ways across the conversation space" $(2004$, p. 8). This multi-centric model is synergistic with Nonnecke and Preece's (1999) finding that lurking is a situated, or contextual, behavior, and it suggests new kinds of research questions: for example, how does knowledge move from space to space? What behaviors and roles are involved? Castro's model provides an incomplete picture in that it accounts only for online activity, yet it is rare for communities to operate purely online (Preece \& Maloney-Krichmar, 2006). Furthermore, ethnographers Garcia, Standlee, Bechkoff, and Cui (2009) convincingly argue that technologically mediated communication is now so strongly merged into daily life that making a distinction between online and offline worlds is of limited use. Citing studies by Lyman and Wakeford (1999) and Ruhleder (2000), Garcia et al. take the stance that "there is one social world that contains both traditional and technologically advanced modes of communication", and that researchers should take account of this multimodal reality, rather than arbitrarily exclude either the virtual arena or the other from their studies (p. 54).

The potential value of integrating face-to-face settings in an ecosystem model of community becomes evident when the offline world is itself conceived of as a set of multimodal, or polycontextual, environments. For example, workplaces are polycontextual in that they involve us in different participation contexts, such as workshops, meetings, and cafes. The co-existence of multiple contexts presents workers with "different, complementary but also conflicting cognitive tools, rules, and patterns of social interaction" (Engeström, Engeström, \& Kärkkäinen (1995, p. 319). Studies of expert cognition have demonstrated that this situation of polycontextuality can contribute to professional learning in situations of novelty (Engeström et. al., 1995; Reder, 1993; Tyre \& von Hippel, 1993) because, as professionals move between different activity contexts, they integrate knowledge from and across them and revise their knowledge in the course of doing so. Building on this stream of work, we argue that it is appropriate to conceptualize today's online communities as part of a larger, polycontextual ecosystem that comprises diverse online and offline settings. We suggest that it is timely for researchers to adopt such a system-level perspective in the framing of studies to foster richer insights about computer-mediated human behaviour. Framing research in this way would require the acknowledgement that members of online forums, chat rooms, and listservs may also interact with one another via other online and/or in face-to-face contexts; settings in which they may be more, or less, visible to their wider community, and where they may act in a variety of different ways. An ecosystem view also suggests the need to revisit what constitutes "the obvious data source" in studies. As Vaast and Walsham (2013) note, many EMSCs present new opportunities to collect and analyze data. Understanding how knowledge is transferred across a polycontextual community ecosystem would require researchers to take an interest in understanding cross-system activity, and the ways in which behaviors that occur in traditional online community contexts relate to behaviors in other parts of the ecosystem. Simplistic role titles (such as poster or lurker) that describe a person's visible contribution in a single context may be limiting if one is seeking to understand the roles, interactions, and contributions of individuals in the larger community ecosystem. On the other hand, contextual behaviors, including lurking, may take on new layers of meaning when viewed from an ecosystem perspective.

\subsection{Summary}

Our literature review highlights several limitations associated with studies of the lurker. Lurking is a contextual behavior rather than the signature of a role that has a clear social meaning, and current understanding of lurking is constrained by the tradition of focusing exclusively on the so-called "obvious" locus of activity-the common online space (typically a forum or discussion board) in which signs of lurking activity are absent. Furthermore, studies do not take account of possible relationships between lurkers and other community members, and the meaning of such relationships. Recent studies suggest that the lurking phenomenon represents a more-complex spectrum of sub-roles or behaviors than once thought: the rare analyses that have investigated behavior in more than one community setting (e.g., Chen \& Chang, 2010; Takahashi et al., 2003) have identified subsets of 
lurkers who transfer knowledge to community members outside of the lurking setting via a different channel. Therefore, it seems likely that much valuable information about lurking lies beyond the traditional boundaries of study. With the increasing uptake of online communication tools and their variety, together with the discovery of communities among Web 2.0 networks, it is timely to investigate the nature of invisible roles more deeply. It is simultaneously important to grapple with the concept of the online community. In a world where the interactions of a community rarely occur with a single online space, it is necessary to move beyond a default, mono-centric view of online community, particularly when considering how knowledge is transferred. Diverse EMSCs and offline contexts contribute to today's polycontextual social world. An ecosystem model that recognizes the overlapping nature of these settings, and the movement of individuals across them, makes it possible to consider how roles foster, or hinder, the flow of knowledge across a community system. There is an opportunity for researchers to revisit and elucidate the phenomenon of invisible or "lurking" behaviors in relationship to such a concept.

\section{Research Method}

Our interest in lurking arose from a larger study that aimed to understand how online communities promoted the transfer and embedding of professional knowledge in, and across, clusters of schools that were participating in a three-year professional development program in New Zealand. In this project, we aimed to identify and understand key roles that contributed to knowledge transfer. Our interest was not in online activities per se, but in how such activities contributed to knowledge transfer in and between communities of practice whose members were based in organizations. New Zealand's school system provided a context in which this issue was strongly topical: the government had embarked on a strategy of embedding knowledge about effective teaching at the system level, while aiming to capitalize on a significant investment in IT infrastructure. Its E-learning Action Plan 2006-2010 emphasized the importance of professional communities, including online communities and networks, in helping to achieve this (Ministry of Education, 2006).

We conducted case research in the interpretive tradition (Klein \& Myers, 1999; Walsham, 1995) by using qualitative methods and taking an inductive approach to analysis. As is consistent with this approach, we did not develop an a priori theoretical model or framework with which to analyze our data. Our theoretical understanding emerged gradually, through the iterative and recursive process of data gathering, analysis, and theory development, and as we alternated between an inductive process of analysis and the interfolding of literature and theory (Eisenhardt, 1989) with emerging findings.

The case was a unique case (Yin, 2003): a three-year national ICT professional development (ICTPD) program in which clusters of schools participated. The program's aim was to integrate ICT into teaching practice in a way that increased teaching effectiveness to support a new, student-centered pedagogy. Appropriating the terminology of some interviewees, we came to call this the new way. For many participants, this amounted to a paradigm shift that challenged their role, their relationship with students, and their understanding of what comprised effective practice. The program used a grassroots model in that clusters were centrally funded but determined their own objectives and approach.

\subsection{Data Collection}

Using purposive sampling, we selected four regionally based clusters of 4-6 schools that had been noted by program officials as having mature online cluster communities. These clusters had been in the ICTPD program for 2-3 years and had undergone professional change according to discussions with key program stakeholders. We gathered data from diverse sources, including 46 interviews, diverse online communication records, program documentation, and later a participant wiki, to corroborate emerging findings. We conducted three rounds of semi-structured interviews. In the first two rounds, we interviewed 41 members of the four official cluster-based communities (communities of educators whose members interacted both online and face-to-face): communities A (14), B (10), C (10), and $D(7)^{3}$. In the third round, we conducted in-depth interviews with five further members of a distributed, intersecting unofficial blog-based community that we discovered during data gathering (in

\footnotetext{
${ }^{3}$ We found that community D's online community had become inactive after having lost its facilitator position.
} 
total, seventeen interviewees participated in this community, Edublog (E)). Study participants were teachers, lead teachers (teachers appointed to change agent roles in the ICTPD program), regular classroom teachers, school leaders (principals and deputy principals), and ICT program facilitators.

We refined our interview questions as our understanding of the study setting improved and as themes emerged. For example, during the early interviews, we found it beneficial to discontinue using the term "online community" to build up a fuller picture of how members communicated online. We used the term only to elicit responses about individuals' forum activity, yet we discovered that a substantial amount of interaction occurred in other online settings. Study participants' initial conceptions of "online community" reflected the traditional concept of online community as single, platform-centric communication setting; however, when asked about their "professional community", they included individuals who interacted outside of the official community platform, and described additional means of communicating online with colleagues. Therefore, using a checklist (email, blogs, Skype, i-chat, Twitter, etc.) as a prompt, we began to ask participants what online tools they used for work-related communication. We asked about how they used these tools, whom they viewed as being important in their professional community, and how they interacted with these people.

During the second round of interviews, we realized that a subset of key individuals across the clusters participated in an additional online community, Edublog. This was an unofficial, highly active, virtual community of leaders, change agents, and facilitators from ICTPD clusters and affiliated New Zealand schools, and was based in in a global network of "edubloggers"-educators who interacted via blogs and other Web 2.0 tools. Our recognition of this community, and our subsequent decision to include it in the study, involved a significant sense-making process as we confronted our own preconceptions. According to our original four-cluster design of the case, we could have considered Edublog to be out of scope. However, we were vexed by the extent of activity in this space, the frequency with which it was mentioned, and its obvious importance to knowledge transfer at the level of the wider case. Furthermore, owing to the fact that it was both non-official and polycentric, Edublog was initially entirely invisible to us-it had no facilitator and was distributed among the blogs of its members. It did not fit our conception of an online community because it was a part of an international network of practice. (It was also a non-canonical community (Brown \& Duguid, 1991)). However, when we returned to the literature, we found that Edublog matched Efimova and Hendrik's (2005) definition of a community because it was situated in an area of strong reciprocal connections in a network. We ascertained this by reviewing interview data, manually tracking online cross-citations, and analyzing blog and twitter "follower" relationships.

Including Edublog in the study made it necessary to elevate our level of analysis to a macro, or system, level: Edublog was not only very different from the other communities, it also transected them. However, we saw clear benefits in allowing this "scope creep". Interviews made it clear that members of this community played a critical and influential role in transmitting knowledge, while a perusal of online content revealed a passion among edubloggers for using IT for student-centered teaching. In order to better understand this community's role, we interviewed five additional Edublog members, and gathered additional data from blogs, Twitter, and selected instant messaging (IM) records.

In order to ascertain how knowledge was transferred and the role of individuals in this process, we needed to understand and focus our attention on the professional knowledge of most relevance to the research setting. By comparing the ICTPD program documentation with interview data, we found that the knowledge of significance comprised a mixture of theory, know-how, values, and beliefs surrounding the use of technology for student-centered, constructivist teaching, which we capture in the phrase the new way (borrowed from a program artefact). We began interviews by asking what participants did differently as a result of engaging in the ICTPD program, such as using a new teaching idea, approach, or method. Many individuals spoke of having taken up an inquiry learning method, using technology for student-driven inquiry, and a shift from seeing themselves as a leader of learning to becoming more of a facilitator. This was associated with a belief that their teaching was now more relevant for students, backed up by stories about pupils' progress. (There was no data available on learning impacts.) We then focused our questioning around how online community interactions had influenced participants in these changes, and encouraged storytelling about the development of their 
new practices and beliefs. During the interviews, several participants showed us the favourites on their laptops-bookmarked blogs, Delicious, Twitter accounts, and RSS feeds. We examined Twitter profiles and blogs to help build up a picture of who followed who, and triangulated this data with crossreferencing of posts and verbal reports to understand and document key interrelationships.

\subsection{Data Analysis}

After transcribing interviews, we emailed them to participants for checking, then analyzed the data, and selected online records using text analysis (Cresswell, 2003) and NVivo software. We followed an inductive, iterative, and evolutionary process (Glaser, 1978; Orlikowski, 1993; Urquhart, 2007): we assigned initial labels based on descriptive keywords and pattern codes, then merged, revised, and added codes as we developed more-abstract themes relating to roles, activities, and knowledge transfer. This recursive analysis process began during data gathering and helped us fine-tune our approach to interviews. Owing to the large amount of online data, we used stories from the interviews and emerging themes from the analysis to guide us to what mattered most in the online records.

Our approach to ensuring credibility and trustworthiness included triangulating reported events with online data sources and running member checks. We relied, in part, on participants' recollections of events that had occurred over a three-year period of professional change. We analyzed online records to help ascertain approximately when reported events had occurred, which compensated for the possible problem of distortions in temporal recall (Wagenaar, 1986). We employed manual backtracking across various communication channel records, extracting time stamped data to trace the emergence and development of key themes, ideas, and practices, and related this back to interview data. By creating several swim-lane diagrams, we recreated experiences and knowledge flows as they had occurred across different channels by integrating online data with reported offline experiences. This labor-intensive activity resulted in a set of valuable explanatory artefacts. We also ran a participant check workshop to confirm emerging findings and followed that up with a feedback wiki, to which six participants contributed.

In our preliminary analysis, we identified 36 brokering activities that we grouped in three categories: filtering and focusing, reinforcing and contextualising, and feeding and helping others ${ }^{4}$. We identified the key roles involved by triangulating interview data (participants' reports of online and offline activities and who was influential) with analysis of interrelationships embedded in blog and forum interactions, bookmarks, RSS feeds, IM records, and Twitter records. As two key unofficial knowledge brokering roles emerged (the subject of this paper), we revisited and simplified the activity code: we re-interpreted them in relationship to these roles and the related activities of leading and following, as reported by both types of brokers. Owing to the invisibility of many of these activities, this round of analysis was informed by the concept of "lurking" (a term used frequently by study participants). Our approach was also informed by an awareness that the nature and value of many of the online activities was largely unrecognized by key stakeholders: while principals were strongly aware of the value of the formal online community (one described the forums as having "sowed the seed" for change), they viewed engagement in Edublog as a pursuit undertaken for personal reasons, with little relevance to the workplace community. Therefore, we focused on identifying the hidden, invisible online activities of those in unofficial roles, and on understanding how these activities contributed to knowledge transfer. We omitted publicly visible blogging activities (most of these were in the category reinforcing and contextualizing, which included remixing and stirring up) and revisited the data, during which we merged some codes and identified new ones (for example, we found that the broker's filtering work involved the use of intermediaries). By the end of this stage, we had identified fourteen invisible brokering activities that we grouped into two major categories ${ }^{5}$.

\section{Findings}

Knowledge transfer occurred through an online community ecosystem, a group of overlapping communities, in which the unofficial community Edublog acted as a critical hub. Although the cluster-

4 See Appendix A.

${ }^{5}$ See Appendix B. 
based communities were linked via an official platform, this drew limited interaction. (A listserv was used only for messages from the program provider. While clusters used forums episodically, crosscluster forums had low engagement.) Online knowledge flow between and in cluster communities occurred largely indirectly via their overlap with Edublog-a nameless, yet well-recognized blogbased community, which one study participant described as "a middle layer of people facilitating [change]". Edublog was united by a passion for, and belief in, ICT's potential to transform learning. These beliefs were closely aligned with the ICTPD program's goals, so involvement in Edublog was an attractive proposition for those spearheading the new way. The community provided a continuous stream of knowledge, persuasive arguments, and practical solutions about the student-centered use of ICT, while its norms encouraged dialogue that sustained this theme.

A subset of seventeen study participants reported regularly engaging with Edublog in some way. In this group, we identified two distinct unofficial, interdependent knowledge broker roles ${ }^{6}$ : eight "visible" connector-leaders and nine "invisible" follower-feeders (individuals who branded themselves as lurkers). One member of community $A$, two of $B$, and one of $C$ were connector-leaders; while one member of $A$, six of $B$, and one of $C$ were follower-feeders. In the final round of interviews, we interviewed five further Edublog members-four connector-leaders and one follow-feeder-who belonged to other cluster communities.) The connector-leaders and follower-feeders brokered knowledge in different ways, at different levels of the ecosystem, and with different levels of online visibility. Despite their very different online activity profiles, both kinds of brokers engaged in invisible online community interactions: they undertook purposive "lurking" to support their knowledge brokering roles. In Section 4.1, we outline the overall community structure in more detail, then describe the two broker roles. Following this, we outline how both kinds of brokers used invisible online activities to facilitate knowledge transfer and help drive professional change.

\subsection{Ecosystem Structure and Roles}

The online community ecosystem across which knowledge flowed comprised three tiers ${ }^{7}$. The first tier was made up of the official cluster-based online communities. The second tier, overlapping with the first, was Edublog, and the third (overlapping with Edublog) was a larger global edublogging community (part of a global network). Edublog functioned as a structural middle layer, or hub. In this ecosystem, we identified a hierarchy of four unofficial roles: (1) regular teachers (RT) who participated infrequently in the online dimension of their cluster-based communities, (2) follower-feeders (FF) who were leaders in their cluster workplace communities and invisible participants in Edublog, (3) connector-leaders $(\mathrm{CL})$ who were cluster community leaders and visible, active members of Edublog, and (4) global leaders (GL) (who we did not interview): prominent bloggers whom the connectorleaders followed and interacted with. The quotes in Table 1 show how the comments of several participants reflected a shared sense of this hierarchical social order.

${ }^{6}$ We use the term knowledge broker to describe someone who actively promotes cross-boundary knowledge flow (Brown \& Duguid, 1998; Davenport \& Prusak, 1998; Harragon \& Sutton, 1997; Pawlowski \& Robey, 2004; Wenger, 1998). By contrast, the broker or social broker (Burt, 1992; Fleming \& Waguespeck, 2007) exploits structural holes in networks by providing the sole connection between groups. We use the term boundary-spanner to describe an individual's spanning position with respect to diverse boundaries.

7 Only three of the cluster communities (A, B, and C) formed part of this online ecosystem. (The fourth community had entered a period of online inactivity). 
Table 1. Quotes from Interviews Illustrating the Perceived Role Hierarchy

1. Regular teacher (RT)

About FFs: She's inspired me... she'll be the one that's on the Internet, and finding all sorts of different things and sharing ideas, and she'll say... "What about trying this?"

They do a lot of work and bring a lot of stuff back to us...it takes the pressure off us.

2. Follower-feeder (FF)

About CLs: I keep an eye on his blog... I've followed his line of thought... I trust the places that [he] goes as being really valuable places to go.

I think if I say something, it might just sound really silly, so I don't say anything. But... the cluster forum, I'll put a comment on that.

About RTs: There are people feeding off me who never go online so I have to go out seeking more to give to them.

\section{Connector-leader (CL)}

About GLs: You've got really innovative and creative and motivational people... sitting up there at the top... they're sparking conversations out... they're the conversation beginners.

It grows and grows and grows, until you're putting a comment on really posh people's blogs. And they're putting comments on yours.

\section{Global leader (GL)}

Not interviewed

One interviewee used the metaphor of a spiral staircase on which various participants were standing: prominent global leaders (the "conversation beginners") were at the top. Underneath them were other global bloggers who created opportunities to "climb on board". Next came the New Zealand edubloggers (connector-leaders) and then those following them (follower-feeders). This staircase metaphor reflected a striking intuitive awareness of the system of stratified leader-follower interactions: regular teachers followed follower-feeders, who followed connector-leaders, who, in turn, followed global leaders.

Online communication among these individuals took place in three broad zones with different levels of online visibility: (1) a publicly visible zone, made up of interlinked online settings in which connector-leaders and global leaders interacted via Web 2.0 tools, (2) a protected, locally visible online zone, where cluster members interacted in official forums, and (3) a invisible online zone of restricted-access settings in which small subsets of connector-leaders and follower-feeders interacted extensively via IM, email, and $\mathrm{SMS}^{8}$. (From an online perspective, face-to-face communication took place invisibly.) Figure 1 shows the interactions between roles associated with these communication zones. Vertical arrows show the key communication means.

${ }^{8}$ Connector-leaders also communicated with each other and their global colleagues invisibly in this zone via IM, Email and sometimes via private tweets (see Figure 1). 


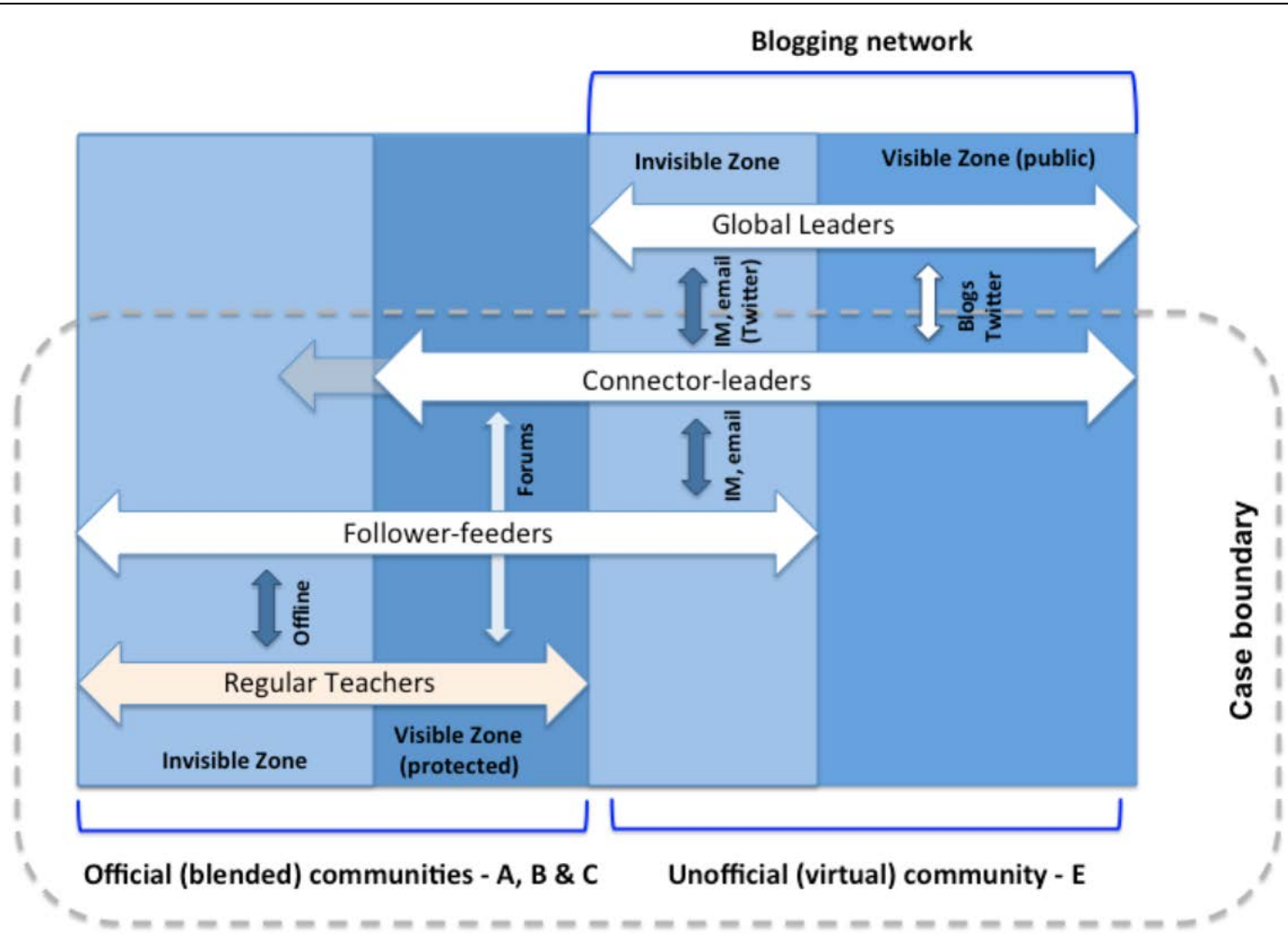

Figure 1. Interactions Between Roles: Communication Zones and Means

The two left-hand columns represent interactions in the cluster communities ( $A, B$, and $C)$. Here, face-to-face (offline) communication occurred between follower-feeders and regular teachers (and local connector-leaders), and locally visible communication occurred in protected (closed) online forums. The two right-hand columns represent Edublog's $(E)$ interactions and communication zones: follower-feeders interacted with connector-leaders in an invisible online zone. (Connector-leaders also communicated with global leaders there.) Communication in the publicly visible zone of Edublog occurred frequently, but only among connector-leaders and global leaders.

The connector-leaders were highly active, respected, and well-connected members of Edublog, and their online influence extended beyond their cluster communities. Their formal roles, as lead teachers or facilitators, provided them with classroom "release time", but their online activities continued well into their personal hours. They made intensive use of a range of communication tools including blogs $^{9}$, wikis, Twitter, IM, social book marking (Delicious), podcasts, and (in some cases) voicethreads and Teacher Tube to promote beliefs, enrich understandings, connect people, and share knowledge about teaching, learning, and technology. They also followed global leaders in a public way by referencing their ideas on their own blogs and communicating with them both visibly (publicly) and invisibly. (One person described this as having "moved into a bigger pond", which reflects an associated sense of status.) Despite placing a high value on publicly visible dialogue, they were well aware of the identities of their local (non-blogging, invisible) followers, and frequently fed them knowledge in the invisible zone via behind-the-scenes means (see Figure 1). In doing this, they filtered and adapted the deluge of new online material to create knowledge of contextual and/or personal relevance (See Section 4.2). Connector-leaders were outward-facing knowledge brokers in that they identified with other online community (Edublog) members, rather than their workplace peers, as their main source of professional support:

\footnotetext{
${ }^{9}$ The privacy settings used for these Web 2.0 tools made them public in most, but not all, cases.
} 
When I had a problem, my blogging community was the one that made me feel better. It wasn't my colleagues in the classroom next door, because they couldn't offer me any advice...It doesn't matter what time it is, you can ask a question, you can ask for some feedback, you can reflect on something,... you can put that out there into the Twitter world, and your community will always come back.

The follower-feeders also held leadership roles that provided classroom release time. (Four were lead teachers in the ICTPD program, and five were curriculum leaders.) However, they remained permanently invisible in Edublog. Lacking the confidence and/or desire to espouse ideas in the public blogosphere, they framed themselves as lurkers (some used more pejorative terms, such as snooper, stalker, parasite, and mosquito, to describe their behavior). Yet they played a considerably more productive role than these terms connote: each follower-feeder followed one or more connectorleader, and communicated regularly with them invisibly. We called them follower-feeders because their identities were bound up with following and feeding on the ideas of online leaders ("I pop in there [to the blogs], and scoff their knowledge and away again"), and also because they selectively "fed" this knowledge on to their own followers, regular teachers, in face-to-face settings: the same teacher who referred to herself as a parasite explained how she passed the ideas she had consumed onto others who fed off her. The allusion to a food chain was striking:

I'm a bit like a parasite. I take up her ideas, and I'm not confident enough to give things back. But I am passing it on to people below me. There are probably people feeding off me, who will never go online, so I have to go out seeking more to give to them. I check things out prior to telling staff. I guess I make decisions about what will work, and what not to tell them.

Despite the self-accusation of parasitism (which has more negative connotations than lurking), we found that follower-feeders provided benefits to Edublog: they fed knowledge about successful ICTbased practices back to connector-leaders, who selectively transferred it back "upwards". In contrast to connector-leaders, follower-feeders were inward-facing knowledge brokers: their identities and loyalties were more strongly bound up with their workplace community than the online community. Whereas the connectors-leader's knowledge-brokering role was performed primarily in an online habitat, the follower-feeder's role centered around bridging online and offline settings. Because the majority of staff in the ICTPD program were regular teachers who had little time to spend online, this brokering work was significant. Like lurkers, follower-feeders left no traces in the blogosphere, but their invisible participation in Edublog was vital to their workplace roles in that it provided a feeding ground and a source of advice. Furthermore, although invisible in Edublog, they had a visible presence in their protected, cluster-based forums. One participant summed up this dual role was summed up as follows:

As far as [the public online community] goes, I'm still at the stage where I'm still learning... but within our own cluster, I would consider myself... to have moved a bit further, and would try to put a bit more of my direction on things... [I'm] a bit more outspoken [in the cluster forum].

\subsection{Invisible Knowledge-Brokering Activities}

Before outlining the invisible activities performed by the knowledge brokers, we more fully outline the nature of the communication environment in which they operated. As connector-leaders participated in a continual distributed dialogue with their peers and followers, they crossed between multiple visible and invisible online (and offline) contexts. Each communication context was a specialized engagement space or activity context (Engeström et. al., 1995), bound up with a context-specific microculture: a set of implicit rules and conventions that governed the nature of the agenda, and the tone, style and register of communication to be used in that engagement space. One connectorleader noted: "Different spaces have different rules; private, shared, public... [The] community develops as we become more comfortable with [using these]". For example, publicly visible blogs demanded well-crafted narrative, citations, and opinions and stories that demonstrated learning. High 
value was placed on new perspectives and inspirational content. In contrast, restricted-visibility forums required staying on topic and responding with arguments to others' ideas. Tweeting culture eschewed formalized statements (partly due to the 140-character limit). It encouraged a personal voice, humour, flippancy, and calls for favours, such as requests for publicly visible feedback on blogs. Although most participants' tweets were technically public, they were considered to be relatively private: they had a short half-life and were viewed only by followers. IM tools (Skype and iChat) were safe, invisible engagement spaces for private, free, and frank discussions in real-time. Crossing between engagement spaces in this system was not simply a matter of choice; it also meant following norms. This required strong sensitivity to contextual needs and opportunities, and skilful application of the rules. The connector-leaders were fluent users of this system and its many niches, while the follower-feeders were adept users of a subset of engagement spaces.

Analysis revealed that both types of knowledge brokers performed a range of invisible activities and "lurked" purposively to support their roles as knowledge transfer and change agents. We grouped these activities in two categories: "managing the knowledge agenda" and "mentoring and being mentored".

Managing the knowledge agenda (selecting and controlling knowledge inputs) comprised five invisible activities: identifying and following influencers, filtering, classifying, using intermediaries, and feeding followers (see Table 2).

Table 2. Managing the Knowledge Agenda

\begin{tabular}{|c|c|c|}
\hline Activity & Description & Example \\
\hline $\begin{array}{l}\text { Identifying } \\
\text { and following } \\
\text { influencers }\end{array}$ & $\begin{array}{l}\text { Identifying people whose } \\
\text { ideas resonate with } \\
\text { change-related goals and } \\
\text { following their online } \\
\text { commentaries }\end{array}$ & $\begin{array}{l}\text { They get time to exercise their minds on how things might } \\
\text { be. So it's like saving me thinking time. They have more } \\
\text { thought about it... I can learn from what they're doing (CL) } \\
\text { I keep an eye out on Jane's blog... I'm reading, looking at } \\
\text { what she's doing, in awe of some of the things that she's } \\
\text { doing (FF) }\end{array}$ \\
\hline Filtering & $\begin{array}{l}\text { Screening online content } \\
\text { to identify relevant, } \\
\text { interesting material }\end{array}$ & $\begin{array}{l}\text { You sort of triage things as they come through your } \\
\text { desktop, and just pick a few things to go back and look at } \\
\text { in more detail, and if it's really good you keep it and share } \\
\text { it (CL) }\end{array}$ \\
\hline Classifying & $\begin{array}{l}\text { Assigning content } \\
\text { classifications/tags that } \\
\text { are meaningful to the } \\
\text { community }\end{array}$ & $\begin{array}{l}\text { I put it into my Delicious, and I mark it for John, or for } \\
\text { Roxanne, so they can link through to it (CL) } \\
\text { mentoring, inquiry learning podcasting, connectivism } \\
\text { (Delicious tags) }\end{array}$ \\
\hline $\begin{array}{l}\text { Using } \\
\text { intermediaries }\end{array}$ & $\begin{array}{l}\text { Identifying individuals with } \\
\text { similar interests and } \\
\text { following their social } \\
\text { bookmarking activity to } \\
\text { help find suitable content }\end{array}$ & $\begin{array}{l}\text { There's about five people... I'll subscribe to their RSS feed } \\
\text { in my Bloglines, and so I see everything that they stick on } \\
\text { their Delicious account... if they're saving something that } \\
\text { I'm interested in, then chances are we're interested in the } \\
\text { same stuff, so I can use them to filter the mass of stuff } \\
\text { that's out there... I use other people as a filter. (CL) }\end{array}$ \\
\hline $\begin{array}{l}\text { Feeding } \\
\text { followers }\end{array}$ & $\begin{array}{l}\text { Alerting followers to } \\
\text { knowledge that matches } \\
\text { their needs through } \\
\text { recommendations/links, or } \\
\text { setting up a private } \\
\text { discussion space to adapt, } \\
\text { develop and build on it }\end{array}$ & $\begin{array}{l}\text { I'll send you a link to what [Frida] had to say about it. } \\
\text { [pastes in URL] (CL to FF, IM) } \\
\text { I'm trying to pull some stuff and see what everyone else is } \\
\text { saying... It's a bit selfish, because I'm not putting anything } \\
\text { out there ... but I am dropping it on the forum (FF) } \\
\text { I brought an idea from Jan's blog back to our group, and } \\
\text { said, "Have you tried this?" (FF) }\end{array}$ \\
\hline
\end{tabular}


Connector-leaders placed high value on meeting their followers' needs. A supply of useful, relevant knowledge was essential to sustain their follower base. On a daily basis, they followed the blogs of selected influencers, and used RSS aggregators to pull feeds from respected tier 4 connections and peers' blogs. (Follower-feeders, who followed fewer blogs, relied on bookmarking rather than RSS feeds.) In selecting which edubloggers to follow, connector-leaders sought out those whose ideas resonated with the community's interests and the ICTPD program's change-related goals and who communicated persuasively. (One connector-leader noted that these people had "time to exercise their minds on how things might be. So it's like saving me thinking time".) Their sustained following of selected bloggers created a trusted stream of incoming knowledge.

Acting as gatekeepers of knowledge, they then undertook filtering: that is, screening and sifting the incoming content to identify material of particular interest, quality, and relevance that fitted their goals, values, and needs. (One participant described this activity as "triage".) One connector-leader who worked as a cluster facilitator noted: "It's just getting an understanding of the way people think, and seeing that there's bits and parts... of what they're saying that fit with what I'm thinking, and what I believe". Filtering provided an opportunity to check on the alignment of one's thinking with respected others and find others in the same "thought stream": "[You can] get the information you want a check of a lot quicker, and from a variety of places, so you can validate it-and see if this stream of thinking is...in other people's places". This validating, or benchmarking, together with the fact that participants followed a common subset of influencers, led to a subtle alignment of ideas and values at system level, which indirectly supported the change agenda of the ICTPD program. The alignment appears to have developed in a subtle, progressive way akin to a contagion; one person noted: "I tend to...look at people who I think are similar to me, or I find myself having similar views to them, and then... it gives a bit of weight to [my ideas]". Indeed, both knowledge and passion were contagious: one follower-feeder commented: "People who write these edublogs are really passionate. I guess some of it rubs off on me."

Having identified suitable incoming knowledge, connector-leaders reacted to chosen "gems": they referenced, reinforced, and recycled the incoming themes on their blogs. To increase relevance, they added local context and commentary, and/or recombined ideas: "I've taken this bit from one person, this bit from someone else, and packaged it up differently". They also commented intermittently on the blogs of influencers. However, this visible activity was like the tip of an iceberg: the vast majority of connector-leaders' following and filtering activities, performed in the invisible margins, left no visible traces at community level. (Follower-feeders remained completely invisible: in blog jargon, they were lurkers—blog readers who leave no trace (Lamb \& Johnson, 2008).)

Connector-leaders tagged their posts and content that had survived the filtering process with thematic labels of relevance, such as inquiry learning, Web 2.0, and collaboration. This classifying activity reframed incoming knowledge according to an unofficial community schema and was done with followers in mind: "I put it into my Delicious, and I mark it for Jim, or for Rosa, so they can link through to it". Followers, alerted to the tagged content via IM, saw this as immensely valuable:

It's like going to the library, and rather than searching for your own good books, some nice librarian... [comes up]... and says, "Here are fifteen books you might well be interested in"... These guys have filtered out a whole lot of good stuff, and so I can focus on reading and thinking about it. (Follower-feeder)

Sharing of folksonomies (material tagged in Delicious) with followers guided their "lurking" and contributed to alignment by defining the agenda for meaning and what ideas mattered. As Balogun, Gleadle, Hailey, and Willmott (2005) note, meanings can be shaped by boundary-spanners to align with change. Connectorleaders also used publicly available Delicious tags to identify third parties with common interests. Using intermediaries involved subscribing to these people's RSS feeds to net more content of relevance. One connector-leader explained: "it's getting other people to do the work for you. I use other people as a filter". Follower-feeders seemed unaware of connector-leaders' skilled use of social bookmarks. They spoke of them spending countless hours looking for content, whereas, in reality, the filtering task was more time-consuming. As the activities of following, filtering, classifying, and using intermediaries were all performed behind the scenes, only connector-leaders shared an understanding of the sophistication and extent of these activities. 
The value of these agenda-setting activities could not be realized without another invisible activity: the proactive feeding of followers. Connector-leaders regularly alerted their known followers to relevant content by sending recommendations and URL links via email and IM, and by sharing it in face-to-face settings: "I rely on Rebecca. ...She finds anything that's worthwhile and she'll alert you to it" (FF). Follower-feeders, acting as second tier gatekeepers, filtered the material that had been fed to them with the needs of regular, "time-poor" teachers in mind: "I check things out prior to telling staff... I make decisions about what will work, and what not to tell them". They then fed selected knowledge to teachers in workshops, syndicate meetings, and informal staffroom discussions (i.e., "I brought an idea from Jan's blog back to our group, and said, 'Have you tried this?"'). These valuable activities left no online trace. Occasionally, they would set up a private forum for their cluster community to discuss material of wider interest with links to the source. (Such discussions were invisible to both the blogging community and the source author.) In sum, the filtering and feeding activities of follower-feeders underline the active role they played in knowledge transfer, and the irony of their self-image as lurkers.

Mentoring and being mentored comprised signalling availability, helpdesking, building up ideas, affirming, buddying, intervening, soliciting, matchmaking, and championing tool use (see Table 3).

Table 3. Mentoring and Being Mentored

\begin{tabular}{|c|c|c|}
\hline Activity & Description & Example \\
\hline $\begin{array}{l}\text { Signalling } \\
\text { availability }\end{array}$ & $\begin{array}{l}\text { Signalling availability for private } \\
\text { interactions (setting online status to } \\
\text { available) }\end{array}$ & $\begin{array}{l}\text { [She] knew I was on-line because I always turn } \\
\text { Skype on so that people know that I'm there...(CL) }\end{array}$ \\
\hline Helpdesking & $\begin{array}{l}\text { Providing an informal real-time } \\
\text { help/advice service }\end{array}$ & $\begin{array}{l}\text { I can talk to her via Skype, and she's very } \\
\text { approachable and she can teach us about just } \\
\text { about [anything]. Just give her a call. (FF) }\end{array}$ \\
\hline $\begin{array}{l}\text { Building up } \\
\text { ideas }\end{array}$ & $\begin{array}{l}\text { Acting as a sounding board; helping } \\
\text { someone test out and develop } \\
\text { ideas (before posting online) }\end{array}$ & $\begin{array}{l}\text { These people that are skyping, or i-chatting } \\
\text { have...faith [in me]. They are saying, "Look, this is } \\
\text { the idea in my head, I'm going to run it past you, } \\
\text { tell me what you think" (CL) }\end{array}$ \\
\hline Affirming & $\begin{array}{l}\text { Giving/receiving approval, praise } \\
\text { and encouragement; } \\
\text { complimenting; being a fan }\end{array}$ & $\begin{array}{l}\text { Just read your reply to Prensky's article. You make } \\
\text { some good points to encourage the conversation } \\
\text { to go further... (CL) }\end{array}$ \\
\hline Buddying & $\begin{array}{l}\text { Engaging with a peer in a sustained } \\
\text { online dialogue/ relationship }\end{array}$ & $\begin{array}{l}\text { It is hard work at times, } i \text { think the facilitators forget } \\
\text { and... forget the other stuff in our lives. (FF, } \\
\text { Skype) }\end{array}$ \\
\hline Soliciting & $\begin{array}{l}\text { Requesting an online contribution; } \\
\text { a call for de-lurking }\end{array}$ & $\begin{array}{l}\text { She sent me an email saying, "I want someone to } \\
\text { comment on this". So I felt obliged, because she } \\
\text { asked me particularly. (CL) }\end{array}$ \\
\hline Matchmaking & $\begin{array}{l}\text { Connecting people to others with } \\
\text { common interests and/or experts }\end{array}$ & $\begin{array}{l}\text { I would actually connect people together. "Have a } \\
\text { talk to this person, they were doing something that } \\
\text { might be quite a good solution for your issue." (CL) }\end{array}$ \\
\hline $\begin{array}{l}\text { Championing } \\
\text { tool use }\end{array}$ & $\begin{array}{l}\text { Promoting the use of tools to } \\
\text { facilitate knowledge acquisition } \\
\text { and/or improved practice }\end{array}$ & $\begin{array}{l}\text { Have you got the Bloglines thing sorted yet to } \\
\text { bring blog feeds to your computer and keep you } \\
\text { up with what's going on at a glance and not have } \\
\text { to spend a lot of time looking for web links? (CL) }\end{array}$ \\
\hline Intervening & $\begin{array}{l}\text { Challenging comments made by } \\
\text { someone in a forum, using a private } \\
\text { channel (via IM) }\end{array}$ & $\begin{array}{l}\text { I saw she was on the I-chat, and I asked her, "Why } \\
\text { do you do that?" (Responding to a post defending } \\
\text { the use of clipart, a facilitator interrupts via IM, } \\
\text { prevailing on a teacher to change her approach) }\end{array}$ \\
\hline
\end{tabular}


Follower-feeders followed up on blog posts invisibly via email and IM to pass on positive feedback (affirming), draw attention to broken links, and seek help and advice. Signalling availability (setting one's IM status as available), combined with a service ethic and a norm of being available afterhours, allowed the connector-leaders to provide an unofficial, distributed, highly personalized helpdesking system for followers and each other. Prior to outlining their views in forums or blog posts, participants reported testing out their emerging thinking in safe, low-visibility settings (IM and/or in the staffroom). Building up ideas involved using respected colleagues as a sounding board. ("These people that are skyping, or ichatting... are saying, 'Look, this is the idea in my head, I'm going to run it past you, tell me what you think.'” $(C L))$. The ensuing discussions required them to articulate and defend their ideas, which helped them flesh out their thinking. For connector-leaders, an outcome of operating across so many engagement spaces was that they built up of their thinking in a progressive way. One of them noted: "Through this dialogue I have to re-define my thinking-By justifying why I think the way I do I clarify in my own head what it is that I do actually believe" (CL, feedback wiki). This quote underlines the perceived impact of invisible online interactions on the development of personal knowledge.

Both connector-leaders and follow-feeders used IM and email for affirming ideas expressed publicly by others. This lowered barriers to engagement and created a supportive atmosphere for those willing to enter into visible online dialogue. Some participants reported more personal buddying relationships in which they engaged with a partner in a sustained online dialogue. Buddies used IM and email for free and frank discussions and for developing shared classroom practices, knowledge, and values. IM and Twitter were used for soliciting engagement; that is, calls for online action, such as asking a colleague to comment on a blog post or voice thread. These calls for "de-lurking" were associated with expectations of dutiful reciprocity. The connector-leaders also undertook matchmaking (linking people to others with relevant knowledge) and championing tool use; for example, calling on a follower to use a RSS aggregators to improve knowledge acquisition. This can also be seen as a call for more-focused and efficient lurking behaviors.

Brokering required decision making about when and where to shift conversations to a different engagement space. Sometimes this involved intervening in a discussion to divert it to a less-public setting. This was typically done to engage a colleague in more frank discussion than was possible in a forum. It allowed the intervening party to express disagreement without the sidelined person losing face. Shifting from a many-to-many to a one-to-one dialogue, and from an asynchronous to synchronous setting, made it possible to extend the (now invisible) discussion and refocus it on changes in individual teaching practice. In one case, a facilitator (CL) used iChat to interrupt a teacher in the classroom: the facilitator challenged her to explain a forum comment defending the use of clipart for a project about camels. The facilitator prompted the teacher to ask the children what they knew about camels, which cornered her into taking a constructivist approach in real-time. In another case, intervening resulted in a more-sustained online buddying relationship between two followerfeeders (see Figure 2): in a forum, Susan expressed frustration with her attempts to introduce Web Quests, an inquiry-based activity in which students gather information from selected websites. Eric, a lead teacher at another school, intervened via IM, and challenged her to persevere. He suggested adapting the approach to make it manageable. Susan tried out Eric's suggestions in class, with mixed results. Over time, she engaged in further IM discussions with Eric about the Web Quest method, and iteratively adapted it for her own purposes. At the end of the reported sequence, Eric intervened, in real time, via IM, into Susan's class, joking, "I hope you're working on the Web Quests!". 


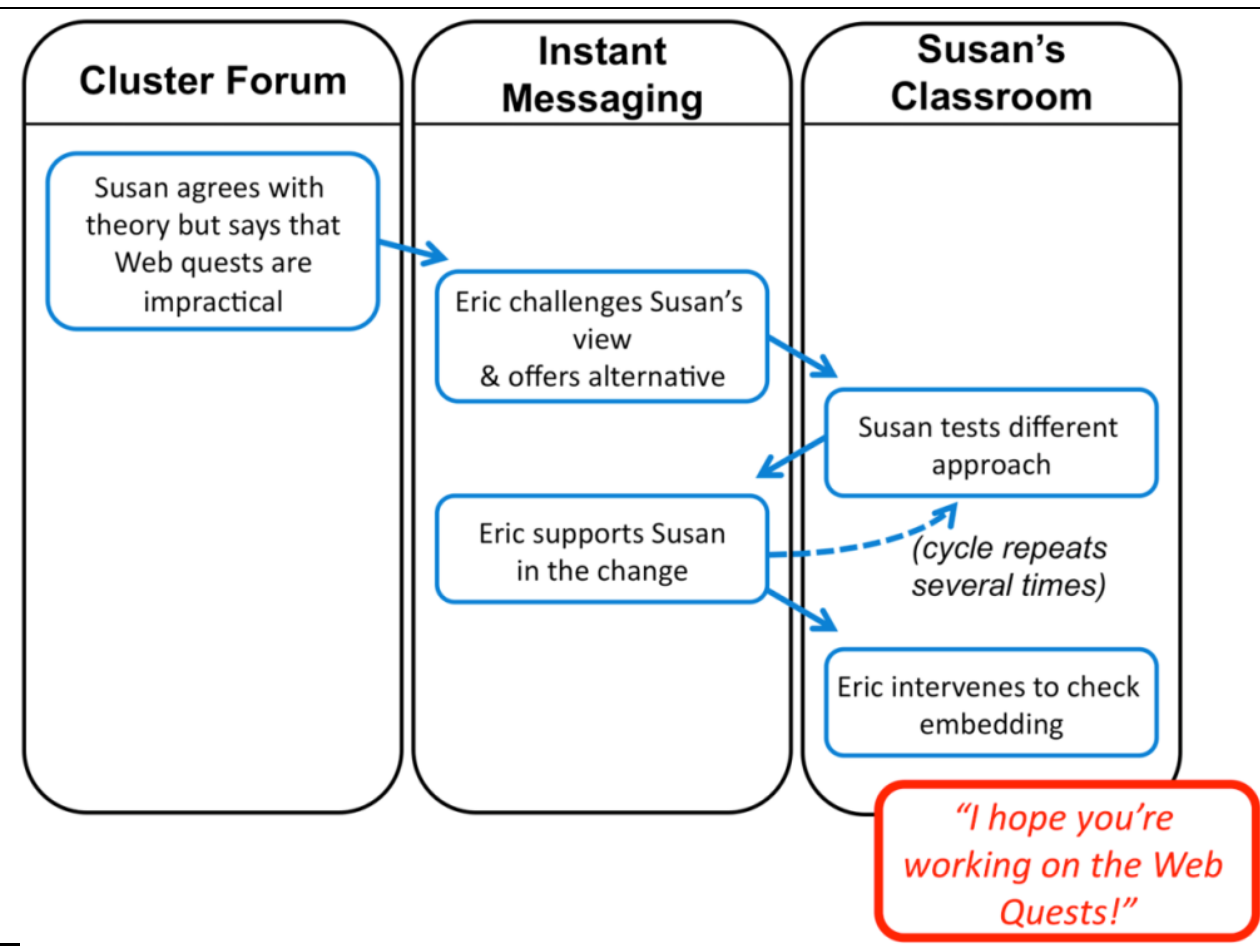

Figure 2. Intervening Using Invisible Engagement Spaces

What is notable in the Web Quests example is that this entire professional learning episode, reported independently by both participants, can only be seen if one tracks the sustained dialogue that occurred across a range of online and offline professional engagement spaces over time: the forum, IM, and Susan's classroom. After Susan's initial critical comment about Web Quests, she does not return to the online forum, while Eric is entirely invisible in it.

If we were to frame this interchange from a traditional lurker perspective, the entire dialogue outside the forum between Susan and Eric would be invisible. We would see Eric as a lurker and Susan as a non-productive online community participant. However, far from being a lurker, Eric is demonstrating a mature contextual awareness by shifting the conversation to an invisible, private space where he can hold a frank discussion with Susan in such way that their status as lead teachers poses no constraints. The significant difference between this multimodal community-as-system view of events and the traditional mono-centric view, which would cast Eric as a lurker, provides a telling illustration of Lubbock's (1892) observation that "What we see depends mainly on what we look for". Only by following the boundary crossing activity and looking beyond the "obvious" online data source can we see what is really happening.

\section{Discussion}

If we had not reframed our level of analysis of online community activity to take an ecosystem perspective, it would have been natural for us to conceive of the follower-feeders as lurkers. We would also have perceived only a fraction of the connector-leaders' knowledge work. Therefore, our reframing decision proved significant: it enabled us to identify patterns of invisible brokering activities that were not simply interesting behaviors, but which comprised a critical driver of knowledge transfer across the community ecosystem. Moving beyond simple information sharing, the activities, in combination, facilitated a deeper embedding of the kind of professional knowledge that is captured in Davenport and Prusak's (1998, p. 5) description: "a fluid mix of framed experience, values, contextual information, and expert insight that provides a framework for evaluating and incorporating new experiences and information, as well as the development of knowledge and values at individual level". As the connector-leaders worked to manage the knowledge agenda, they continually monitored the fit 
of incoming ideas (content, beliefs, and values) with the change agenda. As connector-leaders mentored one another and follower-feeders in the safety of invisible spaces, they worked to align teaching practices with the student-centered approach, and to link up like-minded people. Through the sum of these activities, individuals' knowledge about the new way developed in way that was in tune with the ideas and values of those whom they followed, becoming simultaneously personalized and mutually aligned.

\subsection{Lurking as a Purposive Activity}

We can also see the invisible activities of connector-leaders and follower-feeders as a strategic aspect of their roles. Both groups of knowledge brokers performed the twin roles of leaders and followers: connector-leaders followed global leaders and led follower-feeders, while follower-feeders followed connector-leaders and led regular teachers. The leader or follower role was adopted according to the context the individual was in, whom the person was interacting with, and how the interaction was initiated. For example, when a follower-feeder sent a plea for help to a connectorleader, this cued the connector-leader to take on a leader role, but, when interacting with a global leader, the connector-leader typically assumed a follower role. As they crossed between engagement spaces, the brokers fluidly crossed the leader-follower role boundary. To support these dual roles, they employed lurking purposively, and instinctively packaged up the invisible activities within two broad strategies: Lurking as a leading strategy (employed mainly by connector-leaders) involved invisibly managing the knowledge agenda (by filtering and classifying and by feeding followers) and mentoring others (by feeding ideas to one's followers in private spaces, and/or by intervening privately to challenge statements made in visible community settings). Lurking as a following strategy involved invisibly following and identifying with online influencers, using intermediaries, and being fed and mentored by others. Both kinds of lurking strategies involved making a decision to shift from a particular engagement space to another, at a particular time, and with a particular end in mind.

The value created by their combined activities also bound the two classes of brokers in a symbiotic relationship. While follower-feeders were respected in the classroom, they were novices with low selfesteem in the Edublog community, and identified with the pejorative lurker label ${ }^{10}$. They needed the connector-leaders to keep them near cutting-edge ideas, support them with change, and direct them to third parties who could help develop ideas and solve issues. Similarly, connector-leaders needed follower-feeders to test out their teaching ideas (knowing what worked in the classroom gave them "street cred"), provide practical information, and expand their reach and reputation. This symbiotic relationship brings into question the argument that silent community members should be encouraged to de-lurk or be "promoted" to become online contributors: at the ecosystem level, connector-leaders' value resided largely in online habitats, but the value of follower-feeders lay in their spanning of the online-offline boundary, and in the time, skill, and energy they devoted to converting online knowledge to help drive change in the workplace. The persistence of their "lurking" orientation in Edublog was therefore beneficial to both their school communities and the larger community ecosystem.

\subsection{Polycontextuality as Key to Understanding and Reframing Lurking}

The sophistication and range of invisible brokering activities in this case, and the diversity of settings in which "lurking" occurred, was made possible by the richness and complexity of the online communication environment. In this case, a dramatic increase in the number and variety of online tools, occurring over a three-year period, had transformed the traditional professional environment into a complex, multi-faceted arena for knowledge sharing and interaction. For active online community members, the increased availability of engagement spaces was linked with a higher-thanusual frequency of inter-professional communication, much of it invisible and extending well outside of working hours. The new professional environment was characterized by polycontextuality (i.e., it comprised multiple engagement spaces) and by a notable increase in the number of engagement spaces that were suitable for private, reflective professional dialogue ${ }^{11}$. (The staffroom had previously

10 Their strategic use of lurking behavior to support their follower/leader role illustrates a level of boundary-spanning competence in practice that they did not recognize.

11 The fact that the facilitators and lead teachers were provided with paid daytime release time, which allowed them to spend time online, was also a significant contributor. 
been one of few settings where this could occur.) Barriers to reflection in the traditional workplace are seen as working against the embedding of new knowledge (Leinhardt et al., 1995). By binding up new social technologies with new reflective microcultures, the new polycontextual professional environment militated against this barrier. The new ability to have private discussions online, and a new norm of doing so after-hours, fostered an increase in reflection. Connector-leaders encouraged one another and their followers to reflect on the fit of current teaching practice with theory and beliefs, which promoted iterative changes in practice: "It sort of firms up what you believe, and then you look at what you're doing, and so you change that...." (Lead teacher/CL). Individuals' efforts to integrate and reconcile the theoretical and practical dimensions of practice have been seen as critical to the development of professional knowledge (Bromme \& Tillema 1995; Leinhardt, Young, \& Merriman, 1995; Schön, 1987). Our findings reinforce this theme: crossing between theoretical and practical thinking was a routine dimension of the knowledge brokers' activities, and "reflective lurking" contributed to the embedding of new knowledge.

Note that the invisible activities identified in this study did not arise from lurking decisions alone. For example, a connector-leader's decision to cross from using a forum to using IM might be motivated by concerns about privacy or loss of face, but this decision was embedded in a larger set of decisions concerning the culture of using IM (and the opportunity it provided to reflect on theory-practice alignment), the appropriate role stance to adopt (leader or follower), the recipient's orientation in practice (teacher or edublogger), and their associated communication preferences. The complexity that was routinely involved in these knowledge brokers' work can be understood by viewing them as highly skilled boundary spanners. Boundary spanners are individuals who span different settings or contexts and who understand and bridge their cultures and norms (Awazu, 2004; Levina \& Vaast, 2005; Prusak \& Cross, 2002; Tushman \& Scanlan, 1981). There have been calls for broader, moreflexible approaches to how boundaries are conceived and theorized in IS research (Lindgren, Andersson, \& Henfridsson, 2008; Santos \& Eisenhardt, 2005; Swart, van den Hooff, \& van Baalen, 2011). Notably, Lindgren et al. (2008) highlight the need to recognize multiple co-existing boundaries, while Swart et al. (2011) argue for the inclusion of both virtuality and non-virtuality in relationship to boundary crossing research. Both of these themes were important in this study. The co-existing boundaries that the knowledge brokers successfully negotiated included: 1) the boundaries between the microcultures of engagement spaces (brokers needed to identify suitable spaces, shift between them, and follow their rules), 2) role boundaries (being a leader required a different stance from being a follower), 3) boundaries between different forms of practice (the traditional practice of teaching was very different from the edublogging practice shared by connector-leaders), 4) the boundary between theory and practice, and 5) the online-offline boundary. In particular, follower-feeders' willingness and ability to negotiate the online-offline boundary was critical. Without their invisible online activities, which exposed them to a community of knowledge agents and mentors, they would have been poorly equipped to act as change agents who promoted the student-centered use of ICT in the workplace. Their spanning of the virtual/non-virtual boundary, while entirely invisible, provided significant benefits.

\subsection{The Knowledge Transfer Ecosystem}

The invisible episodes that we outline in this paper occurred as brief snapshots in time in relationship to the sustained, wider pattern of boundary-crossing activity that connector-leaders and followerfeeders engaged in. We can see each online communication event as having at least one precursor event and one or more after-events that took place in a different (or the same) public, protected, or personal setting, either online or offline, with multiple events happening in a day. All this resulted in complex tapestry of knowledge transfer. In order to conceptualize the overall pattern of crossing movement at a high level, we propose a three-level model of the knowledge transfer ecosystem (KTE) based on levels of participant privacy and knowledge discoverability (see Figure 3 ) and spanning both online and offline settings. 


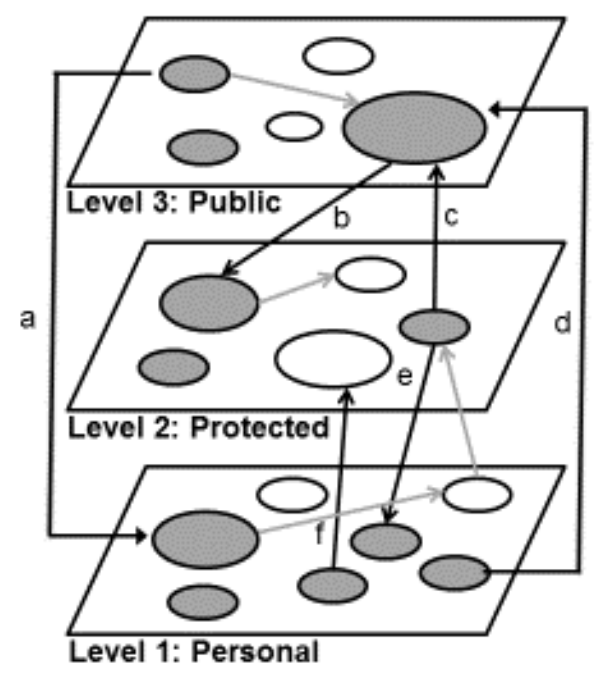

a. FF follows up blog content with author via IM

b. FF adapts blog content for forum post

c. CL reposts comment from forum on blog

d. CL reposts email excerpt on blog

e. CL uses IM to follow up forum comment

f. FF takes ideas from IM chat into workshop

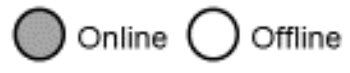

Figure 3. The Knowledge Transfer Ecosystem with Examples of Crossings

At the top is level 3, the public level. This level of the KTE includes online engagement spaces that are publicly visible (e.g., blogs and wikis with open readership) and from which data can be readily discovered, and public face-to-face settings (for example, where public presentations are made). Engaging in visible communication at this level acknowledges a potentially large audience, and is bound up with a sense of confidence and status. Underneath this is the protected level (level 2). Engagement spaces at this level, such as closed forums and blogs and social networking sites are visible only to an authorized group of members or community, and, depending on privacy settings, the data are not publicly accessible. (Drawing on these data records, studies of online communities typically focus on this level.) Face-to-face settings at level 2 (which are typically excluded from these studies) include invitation-only meetings, seminars, and workshops. The personal level of the KTE (level 1) comprises personal engagement spaces such as IM, personal email, and private messages sent via social networking services. These engagement spaces can be used for free and frank discussion, and the arising data are not seen as discoverable to the wider community. (Where email is used for more formal communication with a group it belongs at level 2). Face-to-face engagement spaces at this personal level include settings such as coffee meetings and corridor chats.

Knowledge can flow horizontally (across any level) and vertically (between any two levels) of the KTE. Such flows result from boundary crossings in which brokers convert knowledge into forms suitable for each recipient engagement space and its users. This means endowing knowledge with contextual relevance and meeting the norms for each engagement space's microculture and level of visibility. Figure 3 shows examples, drawn from the research data, of inter-level knowledge flows. Crossing upwards, from level 1 or 2 to level 3, or level 1 to level 2, can be seen as a conscious act of increasing audience. Therefore, this upward movement can be seen to increase the overall pool of publicly accessible knowledge. Upward movement requires a degree of knowledge formalization (for example, committing ideas to a forum at level 2, or posting a public blog post at level 3 . Sensitivity to the originating context is also required. For example, an act of acknowledgement or permission may be necessitated. This is also the case if a personal conversation or IM discussion becomes the basis for a seminar presentation.) Crossing downwards between levels requires adapting, contextualizing, and/or localizing knowledge for a specific community (at level 2) or personalizing it for another individual (level 1). Therefore, it is associated with transferring knowledge to smaller, more specialized audiences. The quality of level 3 knowledge can be seen as being reliant on the quality and diversity of the lower-level sources: as blog content does not come out of thin air and there is a premium placed on originality, ideas need to be sourced from other level 3 settings and/or moved 
upward from levels 2 or 1 . (In this study, connector-leaders sometimes cross-posted previously invisible material from closed forums, Second Life, IM chats, emails, and face-to-face discussions to blogs.) The relevance and quality of source material, in turn, relies on the quality of the knowledge that is accessed and converted to levels 1 and 2 from level 3.

Therefore, knowledge brokers' ability, and the distribution of brokering activity across the ecosystem, are critical in ensuring a virtuous system. In particular, knowledge brokers' ability to practice selective followership and foster followers who trust them, and the level of comfort that brokers at level 3 have for a public role are factors that could either enhance or constrain the extent and quality of knowledge flow at the ecosystem level. In environments that are characterized by change, the degree of fit between the knowledge brokers' values and the change objective is a further factor of relevance.

\section{Implications, Limitations, and Conclusion}

This study has several potential implications for research into the phenomenon of the online community, the wider IS field, and practice.

\subsection{Implications for Research and Researchers}

The popular, pejorative term lurker has been implicitly accepted and reinforced by many studies of online communities. The results of this study challenge the term's meaningfulness as a role concept. While the follower-feeders' persistence in "lurking" in Edublog arose from their orientation away from public exposure, the diverse knowledge-brokering activities that they engaged in while "lurking" were specialized, purposive behaviors that arose from and facilitated their role as workplace leaders and change agents. Our findings show that lurking is not necessarily about a choice to "lurk" but rather may be bound up with a repertoire of more purposive behaviors, including active leadership. Community members who appear invisible in one online setting may be highly active in another setting in which they interact with members of the same community. An apparent decision to lurk may, in reality, be a decision to reroute a discussion into an online setting that is more private and therefore more comfortable for others-a setting that is normally hidden from researchers. The learning of online students has been compared to an iceberg, where most of the mass (their learning) is hidden beneath the surface (Beaudoin, 2002). Better understanding the behaviors and roles of those who appear invisible in online settings will require delving beneath the surface.

The specialized invisible behaviors discovered in this study were not "about" lurking so much as boundary spanning: lurking was a product of sets of diverse, simultaneous boundary-spanning decisions required of knowledge brokers who played specialized unofficial roles as leaders, followers, and go-betweens as they traversed a complex, polycontextual ecosystem. Boundary-spanning theory has its origins in studies of knowledge transfer and learning and is well suited to help understand human behavior in more complex, ICT-infused social environments. Studies of knowledge transfer and innovation have previously uncovered multiple boundary spanning roles and the multidimensional nature of knowledge brokering. With this study, we contribute new insights about the complexity of brokering work by discovering two interdependent broker roles. Our findings suggest there is potential for studies to examine leader-follower relations in other distributed contexts, such as virtual teams, cooperatives, and clusters. There is also potential to explore the microcultures associated with such settings and their impact on knowledge transfer. The theme of symbiosis, the food chain metaphor, and the hierarchy of differentiated roles that emerged in this study are strongly synergistic with an ecosystem perspective. We suggest there is potential to employ boundary-spanning theory in an ecosystem framework; for example, to investigate such themes as niche and habitat boundary in relationship to information systems.

This study demonstrates problems with the default choice of the traditional, platform-centric concept of the online community to frame research into human behaviors in online group settings. Members of today's communities, and workers in many organizations, can engage in multiple online settings, crossing between them, and between these and offline settings. They also spend considerable time in offline settings: as ethnographers have recognized, we inhabit one social world comprising multiple participation contexts. In combination, phenomena such as social media, increasing mobility, 
personalized augmented reality, and the emerging "Internet of things" contribute to a blurring of the old binary division between the online and offline realm, which suggests that this observation has much wider implications for the IS field: can we afford to continue framing studies as if the offline world is separate from the online phenomena of interest? These issues have obvious implications for what researchers see as relevant research questions. They also pose significant challenges for research methods, particularly in relationship to discovering, gathering, and analyzing data, and to privacy and ethical issues. Depending on the questions involved, there may be value in combining ethnographic methods with approaches such as data analytics, social network analysis, and text analysis.

We argue that online activity can only be understood in context when viewed as part of a larger pattern of activity that occurs in and across a knowledge transfer ecosystem. The KTE model recognizes the existence and diversity of multiple engagement spaces while taking a "one social world" approach: online and offline engagement spaces co-exist at three different levels of visibility. Lurking as a phenomenon makes better sense when understood as part of the KTE system: if one's perspective is based at level 3 , activity at other levels will be invisible. This is equally true if the focus is on a single engagement space. (Moving a step further, one could see this study as challenging the value of studying user behavior in relationship to any single IT system in isolation. If one does not account for users' interaction with other systems, we may simply see what we look for (Lubbock, 1892)). The KTE model could be applied in other online community studies and extended to broader IS studies of online workers, virtual teams, multinational corporations, and other settings. However, there are significant challenges and risks in trying to understand a system, particularly in single studies. Valuable insights are likely to arise from cumulative work, but also from studies that examine subsets of engagement spaces. IS researchers could look to the example of scientists and groups who study bio-ecological systems and their component parts.

This study also has a more fundamental implication for IS researchers: it points to an issue in terms of how IS studies are framed. It is usually considered necessary for researchers to select a unit of analysis at the outset of a study, but it is possible that this decision could impede recognition of what is most relevant in the research setting. In the case of our study, framing our study with the online community as the unit of analysis initially prevented us from seeing that the answer to our research lay outside our field of view. Only by tackling our preconceptions and elevating both our perspective and the unit of analysis to a system level did we see what was most relevant to our research goal. Researchers should, therefore, consider allowing some flexibility in research design until after entering a naturalistic research setting and engaging with participants.

\subsection{Implications for Practice}

The study has several implications for practice. First, community managers and stakeholders should ensure that community members are provided with a range of online tools that are appropriate to ensure engagement by those who will not participate in publicly visible contexts, and who prefer the safety of invisible settings. Second, they should take care not to judge the value of an individual's contribution by visible behaviors alone. In this study, follower-feeders played a valuable community role, yet their reluctance to leave traces online meant that their contribution and online engagement was largely invisible. More significantly, school principals significantly underestimated connectorleaders' impact; that is, some of these principals viewed connector-leaders' professional online activities as excessive, eccentric, or lacking in relevance to the real work at hand. Third, in cases where core members have a stronger uptake of online tools than others, managers should work to foster relationships between these people and those with potential to broker knowledge across online/offline boundaries. Fourth, they should not underestimate the importance of offline settings, but recognize them as part of the larger community space, and they should take into account the fact that interactions in face-to-face settings are likely to be discussed among those present using online, behind-the-scenes means.

\subsection{Limitations}

The key limitation of this research project is that, as is typical of interpretive case research, the results are strongly contextual. They are, therefore, unable to be readily transferred to other contexts. As 
interpretivist theory, the results we outline here represent a subjective interpretation of events and their significance. They need to be seen as part of larger set of more-complex events that occurred in reality. Those who seek parsimony and simplicity in IS theory would see these factors as limitations. A further limitation arises from the fact that our understanding of teachers' emerging knowledge and how it impacted their understandings and classroom practice was based largely on their subjective, retrospective reports and recollections. It is not possible to know how closely their reports resembled what actually occurred, but it is likely that hindsight led to some "collapsing" of events. For example, in interviews, some teachers recalled having made a rapid decision to come on board, but facilitators noted that, in their experience, making a decision with this speed had been rare. (Research by Wagenaar (1986) has shown that people's memories can be highly unreliable when it comes to orientating events in time.) We aimed to ascertain the sequence of events by matching up teachers' verbal recollections of events with time-specific online data in forums and/or blogs. However, it was often difficult to establish the exact sequence of reported events. Also, some participants may have exaggerated the extent of online engagement and/or knowledge sharing activities in their reports.

\subsection{Conclusion}

We begin this paper by considering the lurker role. The term lurker is used to describe an individual's lack of discernable activity in a particular online setting, yet, in order to gain an understanding of the significance of lurking, we must consider what the so-called lurker does beyond the confines of the lurking locus. This requires expanding our field of analytical attention to take account of other online and/or offline settings. Building on this argument, we suggest that all participants in online communities can be seen as participating in a larger system of communication contexts or engagement spaces-a polycontextual knowledge transfer ecosystem (KTE). From this ecosystem perspective, individuals are viewed as crossing between diverse online and offline contexts that are associated with varying degrees of visibility, different genres and communication requirements, different benefits, and different sets of co-participants. We suggest that there is opportunity for deep insights to arise if more research into online communities is framed with such a perspective: by seeking to understand the nature of human behaviors in and across the boundaries of an engagement space ecosystem, new insights into communities, online/offline interactions, human behaviors and roles, and associated issues and benefits are likely to emerge. Boundary-spanning theory provides a synergistic lens to help understand and explain human activity in such an ecosystem. Our study of overlapping communities of educators, in which we have applied boundaryspanning theory to reveal and examine the complementary roles played by two kinds of knowledge brokers, provides a glimpse of the potential that the ecosystem perspective offers.

\section{Acknowledgements}

We sincerely thank the associate editor, Remko Helms, and the anonymous reviewers for their valuable contributions throughout the review process. Their critical and constructive suggestions have been very helpful for the development and streamlining of this paper. The research reported here was funded by a grant from the New Zealand Tertiary Education Commission. Thanks to Stanford University's Institute for Research in the Social Sciences for hosting the primary author as visiting scholar during revisions of this paper in 2014. 


\section{References}

Arnold, N., \& Paulus, T. (2010). Using a social networking site for experiential learning: Appropriating, lurking, modeling and community building. The Internet and Higher Education, 13(4), 188-196.

Awazu, Y. (2004). Informal network players, knowledge integration, and competitive advantage. Journal of Knowledge Management, 8(3), 62-70.

Balogun, J., Gleadle, P., Hailey, V., \& Willmott, H. (2005). Managing change across boundaries: Boundary-shaking practices. British Journal of Management, 16(4), 261-278.

Beaudoin, M. F. (2002). Learning or lurking ? Tracking the "invisible" online student. Higher Education, 5, 147-155.

Beaudouin, V., \& Velkovska, J. (1999). The cyberians: An empirical study of sociality in a virtual community. Paper presented at the Ethnographic Studies in Real and Virtual Environments: Inhabited Information Spaces and Connected Communities Conference. Retrieved from www.europhd.net/html/_onda02/04/ss8/.../beaudouin_cyberians_engl.pdf

Bishop, J. (2007). Increasing participation in online communities: A framework for human-computer interaction. Computers in Human Behavior, 23(4), 1881-1893.

Bromme, R., \& Tillema, H. (1995). Fusing experience and theory: The structure of professional knowledge. Learning and Instruction, 5(4), 261-67.

Brown, J., \& Duguid, P. (1991). Organizational learning and communities of practice: Towards a unified view of working, learning and organization. Organization Science, 2(1), 40-57.

Brown, J., \& Duguid, P. (1998). Organizing knowledge. California Management Review, 40(3), 90-111.

Burt, R. S. (1992). Structural holes: The social structure of competition. Cambridge, MA: Harvard University Press.

Castro, M. (2004). The community of practice ecosystem: On competition, cooperation, differentiation, and the role of blogs. Knowledge Board.

Castro, M. (2006). Revisiting communities of practice: From fisherman guilds to the global village. Paper presented at the 3rd European Knowledge Management Network Summer School, Madrid, Spain.

Chen, F., Chang, H., \& Wang, T. (2010). Collective brokering practice: A constellation of practices perspective. In L. Dirckinck-Holmfeld, V. Hodgson, C. Jones, M. de Laat, D. McConnell, \& T. Ryberg (Eds.), Proceedings of the 7th International Conference on Networked Learning (pp. 88-96).

Chen, F., \& Chang, H. (2011). Do lurking learners contribute less ?-A knowledge co-construction perspective. In Proceedings of Community \& Technologies (pp. 169-178). Retrieved from www.iisi.de/fileadmin/IISI/upload/2011/p169_chen.pdf

Cresswell, J. W. (2003). Research design: Qualitative, quantitative, and mixed methods approaches (2nd ed.). Thousand Oaks, CA: Sage.

Davenport, T., \& Prusak, L. (1998). Working knowledge: How organizations manage what they know. Boston: Harvard Business School Press.

De Souza, C. S., \& Preece, J. (2004). A framework for analyzing and understanding online communities. Interacting with Computers: The Interdisciplinary Journal of Human-Computer Interaction, 16(3), 579-610.

Dennen, V. P. (2008). Pedagogical lurking: Student engagement in non-posting discussion behavior. Computers in Human Behavior, 24(4), 1624-1633.

Dubé, L., Bourhis, A., \& Jacob, R. (2006). Towards a typology of virtual communities of practice. Interdisciplinary Journal of Information, Knowledge, and Management, 1, 69-93.

Efimova, L., \& Hendrik, S. (2005). In search for a virtual settlement: An exploration of weblog community boundaries. Paper presented at Communities and Technologies Conference 2005. Retrieved May 10, 2008, from https://doc.telin.nl/dsweb/Get/Document46041/weblog_community_boundaries.pdf

Egan, C., Jefferies, A., \& Johal, J. (2006). Providing fine-grained feedback within an on-line learning system: Identifying the workers from the lurkers and the shirkers. The Electronic Journal of eLearning, 4(1) 15-24.

Eisenhardt, K. (1989). Building theories from case study research. Academy of Management Review, 14(4), 532-550. 
Engeström, Y., Engeström, R., \& Kärkkäinen, M. (1995). Polycontextuality and boundary crossing in expert cognition: Learning and problem solving in complex work activities. Learning and Instruction, 5(4), 319-336.

Fleming, L., \& Waguespack, D. (2007). Brokerage, boundary spanning, and leadership on open innovation communities. Organization Science, 18(2), 165-180.

Garcia, A. C., Standlee, A. I., Bechkoff, J., \& Cui, Y. (2009). Ethnographic approaches to the internet and computer-mediated communication. Journal of Contemporary Ethnography, 38(1), 52-84.

Glaser, B. (1978). Theoretical Sensitivity: Advances in the methodology of grounded theory. Mill Valley, CA: Sociology Press.

Gleave, E., Welser, H., Lento, T., \& Smith, M. (2009). A conceptual and operational definition of 'social role' in online community. In Proceedings of the 42nd Hawaii International Conference on Systems Sciences (pp. 1-11).

Harragon, A., \& Sutton, R. (1997). Technology brokering and innovation in a product development firm. Administrative Science Quarterly, 42, 716-749.

Hodkinson, P. (2004). Subcultural blogging? Individual, community and communication. Paper presented at the Association of Internet Researchers Annual Conference: IR 5.0: Ubiquity.

Jin, B., Park, J. Y., \& Kim, H. (2010). What makes online community members commit? A social exchange perspective. Behaviour \& Information Technology, 29(6), 587-599.

Jones, Q., \& Rafaeli, S. (1999). User population and user contributions to virtual publics: A systems model. In Proceedings of the ACM International Conference on Supporting Group Work (pp. 239-248). ACM Press.

Kaiser, S., Müller-Seitz, G., Pereira Lopes, M., \& Pina e Cunha, M. (2007). Weblog-technology as a trigger to elicit passion for knowledge. Organization, 14(3), 391-412.

Klein, H., \& Myers, M. (1999). A set of principles for conducting and evaluating interpretive field studies. MIS Quarterly, 23(1), 67-93.

Kollock, P., \& Smith, M. (1996). Managing the virtual commons: Cooperation and conflict in computer communities. In S. Herring (Ed.), Computer-mediated communication: Linguistic, social, and cross-cultural perspectives (pp. 109-128). Amsterdam: John Benjamins.

Kucuk, M. (2010). Lurking in online asynchronous discussion. Innovation and creativity in education. Procedia Social and Behavioural Sciences, 2(2), 2260-2263.

Lamb, A., \& Johnson, L. (2008). Blogging: Blog lingo. Escrapbooking. Retrieved January 2, 2014, from http://escrapbooking.com/blogging/lingo.htm

Lave, J., \& Wenger, E. (1991). Situated learning: Legitimate peripheral participation. Cambridge: Cambridge University Press.

Leinhardt, G., Young, K. M., \& Merriman, J. (1995). Integrating professional knowledge: The theory of practice and the practice of theory. Learning and Instruction, 5(4), 401-408.

Leshed, G. (2005). Posters, lurkers, and in between: A multidimensional model of online community participation patterns. Paper presented at the 11th International Conference on HumanComputer Interaction. Retrieved from http://www.cs.cornell.edu/ gl/HCII2005.pdf

Levina, N., \& Vaast, E. (2005). The emergence of boundary spanning competence in practice: Implications for implementation and use of information systems. MIS Quarterly, 29(2), 335-363.

Lindgren, R., Andersson, M., \& Henfridsson, O. (2008). Multi-contextuality in boundary-spanning practices. Information Systems Journal, 18(6), 641-661.

Lubbock, J. (1892). The beauties of nature and the wonder of the world we live in. New York: Macmillan. Retrieved from http://www.archive.org/stream/cu31924031496015\#page/n0/mode/2up

Lyman, P., \& Wakeford, N. (1999). Introduction: Going into the (virtual) field. American Behavioral Scientist, 43(3), 359-376.

Ministry of Education. (2006). Enabling the 21st century learner-an e-learning action plan for schools 2006-2010. Wellington, New Zealand.

Nielsen, J. (2006). Participation inequality: Encouraging more users to contribute. Nielsen Normal Group. Retrieved October 9, 2006, from http://www.useit.com/alertbox/participation_inequality.html

Nonnecke, B. (2000). Lurking in email-based discussion lists (PhD thesis). South Bank University, London. 
Nonnecke, B., \& Preece, J. (1999). Shedding light on lurkers in online communities. In K. Buckner (Ed.), Proceedings of Ethnographic Studies in Real and Virtual Environments: Inhabited Information Spaces and Connected Communities (123-128). Edinburgh.

Nonnecke, B., \& Preece, J. (2000). Lurker demographics: Counting the silent. In Proceedings of the SIGCHI Conference on Human Factors in Computing Systems (pp. 73-80). New York: ACM Press.

Nonnecke, B., Preece, J., Andrews, D., \& Voutour, R. (2004). Online lurkers tell why. Paper presented at the Americas Conference on Information Systems.

Orlikowski, W. (1993). CASE tools are organizational change: Investigating incremental and radical changes in systems development. MIS Quarterly, 17(3), 309-340.

Parks, R., \& Floyd, K. (1996). Making friends in cyberspace. Journal of Computer-Mediated Communication, 1(4).

Pawlowski, S., \& Robey, D. (2004). Bridging user organizations: Knowledge brokering and the work of information technology professionals. MIS Quarterly, 28(4), 645-672.

Phang, C. W., Kankanhalli, A., \& Sabherwal, R. (2009). Usability and sociability in online communities: A comparative study of knowledge seeking and contribution. Journal of the Association for Information Systems, 10(10), 721-747.

Preece, J. (2000). Online communities: Designing usability and supporting socialbilty. New York: John Wiley \& Sons.

Preece, J., Nonnecke, B., \& Andrews, D. (2004). The top five reasons for lurking: improving community experiences for everyone. Computers in Human Behavior, 20(2), 201-223.

Preece, J., \& Maloney-Krochmar, D. (2006). Online communities: Design, theory, and practice. Journal of Computer-Mediated Communication, 10(4).

Prusak, L., \& Cross, R. (2002). The people who make organizations go-or stop. Harvard Business Review, 80(6), 104-112.

Rafaeli, S., Ravid, G., \& Soroka, V. (2004). De-lurking in virtual communities: A social communication network approach to measuring the effects of social and cultural capital. Proceedings of the 2004 Hawaii International Conference on System Sciences.

Ransbotham, S., \& Kane, G. C. (2011). Membership turnover and collaboration success in online communities: Explaining rises and falls from grace in Wikipedia. MIS Quarterly, 35(3), 613-627.

Reder, S. (1993). Watching flowers grow: Polycontextuality and heterochronicity at work. The Quarterly Newsletter of Comparative Human Cognition, 15(4), 116-125.

Ridings, C., Gefen, D., \& Arinze, B. (2006). Psychological barriers: Lurker and poster motivation and behaviour in online communities. Communications of the Association for Information Systems, 18(1), 329-354.

Ruhleder, K. (2000). The virtual ethnographer: Fieldwork in distributed electronic environments. Field Methods, 12(1), 3-17.

Santos, F., \& Eisenhardt, K. (2005). Organizational boundaries and theories of organization. Organization Science, 16(5), 491-508.

Schön, D. A. (1987). Educating the reflective practitioner. San Francisco: Jossey-Bass.

Soroka, V., \& Rafaeli, S. (2006). Invisible participants: How cultural capital relates to lurking behaviour. Proceedings of the 2006 International Conference on the World Wide Web 2006. Retrieved from http://doi.acm.org/10.1145/1135777.1135806

Swart, J., van den Hooff, B., \& van Baalen, P. (2011). Connecting worlds. Management Learning, 42(4), 371-377.

Takahashi, M., Fujimoto, M., \& Yamasaki, N. (2003). The active lurker: Influence of an in-house online community on its outside environment. Paper presented at the Proceedings of the 2003 International ACM SIGGROUP Conference on Supporting Group Work. Retrieved from: http://waterwiki.net/images/8/89/The_Active_Lurker_Influence_of_an_Inhouse_Online_Community_on_its_Outside_Environment.pdf

Tushman, M., \& Scanlan, T. (1981). Boundary spanning individuals: Their role in information transfer and their antecedents. Academy of Management Journal, 24(2), 289-305.

Tyre, M., \& von Hippel, E. (1997). The situated nature of adaptive learning in organizations. Organization Science, 8(1), 71-83.

Urquhart, C. (2007). The evolving nature of grounded theory method: The case of the information systems discipline. In A. Bryant \& K. Charmaz (Eds.), The Sage handbook of grounded theory (339-359). Thousand Oaks, CA: Sage. 
Vaast, E., \& Walsham, G. (2013). Grounded theorizing for electronically mediated social contexts. European Journal of Information Systems, 22(1), 9-25.

Wagenaar, W. (1986). My memory: A study of autobiography memory over six years. Cognitive Psychology, 18(2), 225-252.

Walsham, G. (1995). Interpretive case studies in IS research: Nature and method. European Journal of Information Systems, 4(2), 74-81.

Wang, X., \& Yu, Y. (2012). Classify participants in online communities. International Journal of Managing Information Technology, 4(1), 1-13.

Wasko, M., \& Faraj, S. (2005). Why should I share? Examining social and knowledge capital contribution in electronic networks of practice. MIS Quarterly, 29(1), 35-57.

Wasko, M., Teigland, R., \& Faraj, S. (2009). The provision of online public goods: Examining social structure in an electronic network of practice. Decision Support Systems, 47(3), 254-265.

Waters, J., \& Gasson, S. (2006). Social engagement in an online community of inquiry. Proceedings of the International Conference on Information Systems. Retrieved from http://aisel.aisnet.org/icis2006/47.

Wei, C. (2004). Formation of norms in a blog community. Into the blogosphere; rhetoric, community and culture of weblogs. In S. A. L. Gurak, L. Johnson, C. Ratliff, \& J. Reyman (Ed.), Into the blogosphere; Rhetoric, community and culture of weblogs. Minnesota: University of Minnesota. Retrieved from http://blog.lib.umn.edu/blogosphere/formation_of_norms.html

Wenger, E. (1998). Communities of practice: Learning, meaning, and identity. Cambridge: Cambridge University Press.

Whittaker, S., Terveen, L., Hill, W., Cherny, L., Ave, P., \& Park, F. (1998). The dynamics of mass interaction. Proceedings of the ACM Conference on Computer-Supported Cooperative Work.

Yin, R. (2003). Case study research, design and methods (3rd ed.). Newbury Park: Sage. 


\section{Appendices}

\section{Appendix A}

Table A-1 shows the three categories of knowledge-brokering activities that we identified prior to the lurking-focused analysis. This analysis focused on identifying online brokering activities regardless of their degree of visibility. Bolded text shows categories and codes that we omitted from the subsequent lurking-focused analysis due to their lack of relevance (e.g., due to high visibility).

Table A-1. Online Knowledge-Brokering Activity Codes

Category 1: Filtering and focusing

\begin{tabular}{|c|c|c|}
\hline Activity & Explanation (and tools used) & Example \\
\hline $\begin{array}{l}\text { Establishing foci: Selecting } \\
\text { guiding/framing foci. }\end{array}$ & $\begin{array}{l}\text { Aids focusing; reduces noise of } \\
\text { web content (RSS feeds). }\end{array}$ & $\begin{array}{l}\text { One of the focusses [sic] that I've got } \\
\text { is trying to figure out what it is about } \\
\text { gaming, and the on-line environment } \\
\text { in general really, that's so engaging } \\
\text { for kids, and thinking about what it is } \\
\text { that we can build into our pedagogy } \\
\text { that we can learn from that. }\end{array}$ \\
\hline $\begin{array}{l}\text { Scanning, screening and } \\
\text { filtering: Scanning content } \\
\text { using foci to screen and } \\
\text { filter. }\end{array}$ & $\begin{array}{l}\text { Enhances focusing by aggregating } \\
\text { content on relevant themes (RSS } \\
\text { feeds). }\end{array}$ & $\begin{array}{l}\text { [My job] was going out there and } \\
\text { finding all this stuff, and reading lots } \\
\text { of things, and just taking out the } \\
\text { gems to share. And she liked just } \\
\text { being able to go somewhere to get } \\
\text { the good stuff, rather than having to } \\
\text { search for herself. And that's what I } \\
\text { still try and do... }\end{array}$ \\
\hline $\begin{array}{l}\text { Following: Following } \\
\text { respected, influential } \\
\text { people and/or colleagues. }\end{array}$ & $\begin{array}{l}\text { Facilitates aligning of ideas; } \\
\text { Topical shifts in themes keep ideas } \\
\text { fresh and create conversation } \\
\text { hubs (re-focusing) (Tagging/RSS } \\
\text { feeds, email, Twitter, IM). }\end{array}$ & $\begin{array}{l}\text { I might subscribe to two or three } \\
\text { extra people in my bloglines who are } \\
\text { talking about that particular thing at } \\
\text { the moment... }\end{array}$ \\
\hline $\begin{array}{l}\text { Filtering for quality } \\
\text { ("triage"): Screening } \\
\text { material for relevance and } \\
\text { quality. }\end{array}$ & $\begin{array}{l}\text { Ensures attention is given to } \\
\text { quality, relevant material; } \\
\text { condenses CoP inputs (aids } \\
\text { focusing) (Decision may be } \\
\text { supported by Skype/ iChat). }\end{array}$ & $\begin{array}{l}\text { You sort of triage things as they } \\
\text { come through your desktop, and just } \\
\text { pick a few things to go back and look } \\
\text { at in more detail, and if it's really } \\
\text { good you keep it and share it, and if } \\
\text { it's not, it's just gone. }\end{array}$ \\
\hline $\begin{array}{l}\text { Sorting and classifying: } \\
\text { Sorting and classifying } \\
\text { content into familiar } \\
\text { categories (community } \\
\text { taxonomy). }\end{array}$ & $\begin{array}{l}\text { Content is contextualized by } \\
\text { sorting into categories relevant to } \\
\text { CoP, and tagging, promoting } \\
\text { focusing, and aligning (social } \\
\text { bookmarking: Delicious). }\end{array}$ & $\begin{array}{l}\text { I've got access to my Delicious } \\
\text { account through my blog... people } \\
\text { can click on it and go and see the } \\
\text { things that I've [tagged]. }\end{array}$ \\
\hline
\end{tabular}


Table A-1. Online Knowledge-Brokering Activity Codes (cont.)

Category 2: Reinforcing and contextualizing

\begin{tabular}{|c|c|c|}
\hline Activity & Explanation (and tools used) & Example \\
\hline $\begin{array}{l}\text { Promoting: Citing or } \\
\text { recommending a blog post } \\
\text { or presentation by another } \\
\text { person. }\end{array}$ & $\begin{array}{l}\text { Amplifies significance of message; } \\
\text { drives followers to source } \\
\text { (persuading others while aligning } \\
\text { with source) (Blogs, Online } \\
\text { Videos, Tagging, RSS Feeds). }\end{array}$ & $\begin{array}{l}\text { I was reading [named leader]'s } \\
\text { School } 2.0 \text { blog yesterday and as I } \\
\text { cycled through the streets... I began } \\
\text { to give it some more thought. }\end{array}$ \\
\hline $\begin{array}{l}\text { Extending: using someone } \\
\text { else's (referenced) blog } \\
\text { post as a springboard for } \\
\text { one's own thoughts (also } \\
\text { described as } \\
\text { piggybacking). }\end{array}$ & $\begin{array}{l}\text { Adds local value and relevance by } \\
\text { contextualising content. } \\
\text { Reinforces by adding weight of } \\
\text { local author, who gains further } \\
\text { credibility through association with } \\
\text { the cited material/author (blogs, } \\
\text { online videos, tagging, RSS } \\
\text { Feeds) }\end{array}$ & $\begin{array}{l}\text { New conversations are always } \\
\text { happening, but then we're } \\
\text { sometimes going back to the old } \\
\text { conversation and putting a new spin } \\
\text { on it. (Connector-leader) }\end{array}$ \\
\hline $\begin{array}{l}\text { Stirring up: As above, but } \\
\text { disagreeing with a } \\
\text { referenced source. }\end{array}$ & $\begin{array}{l}\text { As above, but may trigger deeper } \\
\text { engagement of readers with } \\
\text { concepts as they are challenged to } \\
\text { take and justify a stance } \\
\text { (promotes stronger focusing). }\end{array}$ & $\begin{array}{l}\text { sometimes I'll get on a soap-box a bit } \\
\text { to be a bit provocative, and see what } \\
\text { I can stir up. }\end{array}$ \\
\hline $\begin{array}{l}\text { Tagging: Tagging } \\
\text { referenced material with } \\
\text { categories relevant to the } \\
\text { community and/or the } \\
\text { originator's name. }\end{array}$ & $\begin{array}{l}\text { Alerts community members and/or } \\
\text { the content originator to a relevant } \\
\text { posting (based on familiar } \\
\text { categories) (blogs, tagging, RSS } \\
\text { feeds, email). }\end{array}$ & $\begin{array}{l}\text { I put it into my Delicious, and I mark it } \\
\text { for [Allan], or for [Susan], so they can } \\
\text { link through to it that way. }\end{array}$ \\
\hline $\begin{array}{l}\text { Commentating in a } \\
\text { group: Commentating on a } \\
\text { blog or conference keynote } \\
\text { to contextualise it, adding } \\
\text { local/personal opinion. }\end{array}$ & $\begin{array}{l}\text { Contextualises a real-time } \\
\text { presentation, promoting a shared } \\
\text { interpretation (focusing, aligning) } \\
\text { (Twitter, Skype/iChat) }\end{array}$ & $\begin{array}{l}\text { After I...[had] more contact with } \\
\text { people within the conference via } \\
\text { twitters it changed the dimension } \\
\text {...from being...thoughts between the } \\
\text { speaker and myself to the possibility } \\
\text { of having other people's opinions... } \\
\text { the twitters and examples that were } \\
\text { given in rebuttal or agreement...I was } \\
\text { questioning and thinking during the } \\
\text { keynote to a higher dimension than if } \\
\text { I was just sitting there listening. }\end{array}$ \\
\hline $\begin{array}{l}\text { Remixing: Juxtaposing } \\
\text { content from different } \\
\text { sources to make a point; } \\
\text { giving a new "spin". }\end{array}$ & $\begin{array}{l}\text { Novelty helps gain attention and } \\
\text { can generate new insights } \\
\text { (blogs, tagging, RSS feeds). }\end{array}$ & $\begin{array}{l}\text { I've taken this bit from one person, } \\
\text { this bit from someone else, and } \\
\text { packaged it up differently. }\end{array}$ \\
\hline $\begin{array}{l}\text { Echoing/resonating: } \\
\text { Writing a blog post that } \\
\text { resonates with previously } \\
\text { introduced themes (without } \\
\text { referencing "source") }\end{array}$ & $\begin{array}{l}\text { Recycling familiar themes from a } \\
\text { new angle (aligning) reinforces } \\
\text { concepts. Lack of citation } \\
\text { suggests owning of concepts } \\
\text { (blogs, tagging, RSS feeds). }\end{array}$ & $\begin{array}{l}\text { Unconscious reuse of metaphors/ } \\
\text { themes from an influential You Tube } \\
\text { video is found through textual } \\
\text { analysis of a later blog post. }\end{array}$ \\
\hline
\end{tabular}


Table A-1. Online Knowledge-Brokering Activity Codes (cont.)

Category 3: Feeding and helping others

\begin{tabular}{|c|c|c|}
\hline Activity & Explanation (and tools used) & Example \\
\hline \multicolumn{3}{|c|}{ Feeding } \\
\hline $\begin{array}{l}\text { Matching: Matching } \\
\text { incoming online (blog) } \\
\text { content to known needs of } \\
\text { clusters and individuals. }\end{array}$ & $\begin{array}{l}\text { Ensures delivery of relevant } \\
\text { content, aiding ability of recipient } \\
\text { to interpret, embed and enact new } \\
\text { knowledge (IM, email). }\end{array}$ & $\begin{array}{l}\text { It's just getting an understanding of } \\
\text { the way other people think, and } \\
\text { seeing that there's ...parts of what } \\
\text { they're saying that fit with what I'm } \\
\text { thinking, and what I believe. }\end{array}$ \\
\hline $\begin{array}{l}\text { Passive feeding: Tagging } \\
\text { content so it can be } \\
\text { accessed by others (see } \\
\text { also sorting and classifying } \\
\text { above). }\end{array}$ & $\begin{array}{l}\text { Results in feeding of followers who } \\
\text { use RSS feeds and bookmarks; } \\
\text { promotes focusing } \\
\text { (tagging, RSS feeds). }\end{array}$ & $\begin{array}{l}\text { I put it into my Delicious and I mark it } \\
\text { for [Allan], or for [Susan], so } \\
\text { they can link through to it that way. }\end{array}$ \\
\hline $\begin{array}{l}\text { Active feeding: Alerting } \\
\text { individuals who have } \\
\text { limited online time to } \\
\text { specific relevant blog/online } \\
\text { content. }\end{array}$ & $\begin{array}{l}\text { Personalising content, combined } \\
\text { with individual attention, builds } \\
\text { relevance and owning; sustains } \\
\text { focusing (email, Skype/iChat, } \\
\text { Twitter) }\end{array}$ & $\begin{array}{l}\text { I rely on Rebecca. She spends } \\
\text { hours and hours looking at blogs ... } \\
\text { She finds anything that's worthwhile, } \\
\text { and she'll alert you to it... } \\
\text { I'm a bit like a parasite. I take up her } \\
\text { ideas, and I'm not confident } \\
\text { enough to give things back. But I am } \\
\text { passing it on to people below me. }\end{array}$ \\
\hline \multicolumn{3}{|c|}{ Helping others } \\
\hline $\begin{array}{l}\text { Being available: } \\
\text { Community culture involves } \\
\text { long periods of being } \\
\text { continuously available } \\
\text { online. }\end{array}$ & $\begin{array}{l}\text { Mutual facilitation of just-in-time } \\
\text { support service supports adapting } \\
\text { and promotes aligning } \\
\text { (Twitter, Skype/iChat) }\end{array}$ & $\begin{array}{l}\text { It doesn't matter what time it is, } \\
\text { you can ask a question, you can ask } \\
\text { for some feedback... say you've got } \\
\text { a technical problem, you can put that } \\
\text { out there into the Twitter world, and } \\
\text { your community will always come } \\
\text { back. }\end{array}$ \\
\hline $\begin{array}{l}\text { Sharing successes and } \\
\text { problems: Sharing and } \\
\text { celebrating success. }\end{array}$ & $\begin{array}{l}\text { A form of persuading that sustains } \\
\text { beliefs and commitment } \\
\text { (Twitter, Skype/iChat). }\end{array}$ & $\begin{array}{l}\text { All but four in my class... are within a } \\
6 \text {-month range of their age yippee! } \\
\text { Must be the technology in my room } \\
\text { tee-hee. (Tweet) }\end{array}$ \\
\hline $\begin{array}{l}\text { Testing and benchmarking: } \\
\text { Testing out ideas with } \\
\text { colleagues, making } \\
\text { comparisons about ideas } \\
\text { implemented in different } \\
\text { contexts. }\end{array}$ & $\begin{array}{l}\text { Practical support for embedding as } \\
\text { ideas and practices evolve; } \\
\text { promotes aligning (Twitter, } \\
\text { Skype/iChat). }\end{array}$ & $\begin{array}{l}\text { If we'd had a visiting speaker... } \\
\text { we talked a bit about that [on } \\
\text { Skype].... bouncing ideas off } \\
\text { each other...saying, "I'm going to try } \\
\text { this in the classroom", or ... saying, } \\
\text { "I tried this today" and telling them } \\
\text { how it went. }\end{array}$ \\
\hline
\end{tabular}




\section{Table A-1. Online Knowledge-Brokering Activity Codes (cont.)}

Category 3: Feeding and helping others

\begin{tabular}{|l|l|l|}
\hline \multicolumn{1}{|c|}{ Activity } & Explanation (and tools used) & \multicolumn{1}{c|}{ Example } \\
\hline $\begin{array}{l}\text { Brokering connections and } \\
\text { solutions: brokering connections } \\
\text { between local community } \\
\text { members and technology or } \\
\text { educational experts/practitioners. }\end{array}$ & $\begin{array}{l}\text { Practical support for followers as } \\
\text { they implement new processes } \\
\text { and technologies (adapting) } \\
\text { (Twitter, Skype/iChat, email). }\end{array}$ & $\begin{array}{l}\text { I would actually connect people... } \\
\text { "Have a talk to this person, they } \\
\text { were doing something that might } \\
\text { be quite a good solution for your } \\
\text { issue." }\end{array}$ \\
\hline $\begin{array}{l}\text { Defending the community: } \\
\text { Defending community members } \\
\text { who are under attack, using } \\
\text { supportive comments/arguments. }\end{array}$ & $\begin{array}{l}\text { Reinforces community beliefs } \\
\text { and asserts aligning. Bolsters } \\
\text { individual morale by defending } \\
\text { against non-aligned views (blog, } \\
\text { Twitter, Skype/IM). }\end{array}$ & $\begin{array}{l}\text { [That person was] challenging } \\
\text { us...to justify why we think what } \\
\text { we're thinking. That's good... } \\
\text { that's the only way that we move } \\
\text { forward, and solidify our } \\
\text { position... }\end{array}$ \\
\hline
\end{tabular}




\section{Appendix B}

Table B-1 shows the revised codes and categories after our "lurking"-focused re-analysis. The analytical focus here was on identifying "invisible" online knowledge-brokering activities performed by both connector-leaders and follower-feeders, so it was necessary to re-examine some data. We have amended the names for categories 1 and 3 to capture this concept and reflect the perspective of follower-feeders. The new codes are shown in bold. We renamed some codes from Table A-1 (Appendix A) or merged them into new parent codes.

\section{Table B-1. Invisible Online Knowledge-Brokering Activity Codes}

Category 1: Managing the knowledge agenda

\begin{tabular}{|c|c|c|}
\hline Activity & Description & Example \\
\hline $\begin{array}{l}\text { Identifying and } \\
\text { following } \\
\text { influencers. }\end{array}$ & $\begin{array}{l}\text { Identifying people whose } \\
\text { ideas resonate with change- } \\
\text { related goals and following } \\
\text { their online commentaries. }\end{array}$ & $\begin{array}{l}\text { They get time to exercise their minds on how } \\
\text { things might be. So it's like saving me thinking } \\
\text { time. They have more thought about it... I can } \\
\text { learn from what they're doing. (CL) } \\
\text { I keep an eye out on Jane's blog... I'm reading, } \\
\text { looking at what she's doing, in awe of some of the } \\
\text { things that she's doing. (FF) }\end{array}$ \\
\hline Filtering. & $\begin{array}{l}\text { Screening online content to } \\
\text { identify relevant, interesting } \\
\text { material. }\end{array}$ & $\begin{array}{l}\text { You sort of triage things as they come through } \\
\text { your desktop, and just pick a few things to go } \\
\text { back and look at in more detail, and if it's really } \\
\text { good you keep it and share it. (CL) }\end{array}$ \\
\hline Classifying. & $\begin{array}{l}\text { Assigning content } \\
\text { classifications/tags that are } \\
\text { meaningful to the community. }\end{array}$ & $\begin{array}{l}\text { I put it into my Delicious, and I mark it for John, or } \\
\text { for Roxanne, so they can link through to it. (CL) } \\
\text { mentoring, inquiry learning podcasting, } \\
\text { connectivism. (Delicious tags) }\end{array}$ \\
\hline $\begin{array}{c}\text { Using } \\
\text { intermediaries. }\end{array}$ & $\begin{array}{l}\text { Identifying individuals with } \\
\text { similar interests and following } \\
\text { their social bookmarking } \\
\text { activity to help find suitable } \\
\text { content. }\end{array}$ & $\begin{array}{l}\text { There's about five people... I'll subscribe to their } \\
\text { RSS feed in my Bloglines, and so I see } \\
\text { everything that they stick on their Delicious } \\
\text { account... if they're saving something that I'm } \\
\text { interested in, then chances are we're interested in } \\
\text { the same stuff, so I can use them to filter the } \\
\text { mass of stuff that's out there... I use other people } \\
\text { as a filter. (CL) }\end{array}$ \\
\hline Feeding followers. & $\begin{array}{l}\text { Alerting followers to } \\
\text { knowledge that matches their } \\
\text { needs through } \\
\text { recommendations/links; } \\
\text { setting up a private } \\
\text { discussion area to adapt, } \\
\text { develop/build on it. }\end{array}$ & $\begin{array}{l}\text { I'll send you a link to what [Frida] had to say } \\
\text { about it. [pastes in URL] (CL to FF, IM) } \\
\text { It's a bit selfish, because I'm not putting anything } \\
\text { out there ... but I am dropping it on the forum. } \\
\text { (FF) } \\
\text { I brought an idea from Jan's blog back to our } \\
\text { group, and said, "Have you tried this?" (FF) }\end{array}$ \\
\hline
\end{tabular}


Table B-1. Invisible Online Knowledge-Brokering Activity Codes (cont.)

Category 2: Mentoring and being mentored

\begin{tabular}{|c|c|c|}
\hline Activity & Description & Example \\
\hline $\begin{array}{l}\text { Signalling } \\
\text { availability. }\end{array}$ & $\begin{array}{l}\text { Signalling availability for } \\
\text { private interactions (setting } \\
\text { online status as available). }\end{array}$ & $\begin{array}{l}\text { [She] knew I was on-line because I always turn } \\
\text { Skype on so that people know that I'm there... } \\
\text { (CL) }\end{array}$ \\
\hline Helpdesking. & $\begin{array}{l}\text { Providing an informal real- } \\
\text { time help/advice service. }\end{array}$ & $\begin{array}{l}\text { I can talk to her via Skype, and she's very } \\
\text { approachable and she can teach us about just } \\
\text { about [anything]. Just give her a call. (FF) }\end{array}$ \\
\hline Building up ideas. & $\begin{array}{l}\text { Acting as a sounding board; } \\
\text { helping someone test out and } \\
\text { develop ideas (before posting } \\
\text { online). }\end{array}$ & $\begin{array}{l}\text { These people that are skyping, or i-chatting } \\
\text { have...faith [in me]. They are saying, "Look, this } \\
\text { is the idea in my head, I'm going to run it past } \\
\text { you, tell me what you think.". (CL) }\end{array}$ \\
\hline Affirming. & $\begin{array}{l}\text { Giving/receiving approval, } \\
\text { praise and encouragement; } \\
\text { complimenting; being a fan. }\end{array}$ & $\begin{array}{l}\text { Just read your reply to Prensky's article. You } \\
\text { make some good points to encourage the } \\
\text { conversation to go further... (CL) }\end{array}$ \\
\hline Buddying. & $\begin{array}{l}\text { Engaging with a peer in a } \\
\text { sustained online dialogue/ } \\
\text { relationship. }\end{array}$ & $\begin{array}{l}\text { It is hard work at times, } i \text { think the facilitators } \\
\text { forget and... forget the other stuff in our lives. } \\
\text { (FF, Skype) }\end{array}$ \\
\hline Soliciting. & $\begin{array}{l}\text { Requesting an online } \\
\text { contribution; a call for de- } \\
\text { lurking. }\end{array}$ & $\begin{array}{l}\text { She sent me an e-mail saying, "I want someone } \\
\text { to comment on this". So I felt obliged, because } \\
\text { she asked me particularly. (CL) }\end{array}$ \\
\hline Matchmaking. & $\begin{array}{l}\text { Connecting people to others } \\
\text { with common interests and/or } \\
\text { experts. }\end{array}$ & $\begin{array}{l}\text { I would actually connect people together [and } \\
\text { say], "Have a talk to this person, they were doing } \\
\text { something that might be quite a good solution for } \\
\text { your issue.". (CL) }\end{array}$ \\
\hline $\begin{array}{l}\text { Championing tool } \\
\text { use. }\end{array}$ & $\begin{array}{l}\text { Promoting the use of tools to } \\
\text { facilitate knowledge } \\
\text { acquisition and/or improved } \\
\text { practice. }\end{array}$ & $\begin{array}{l}\text { Have you got the Bloglines thing sorted yet to } \\
\text { bring blog feeds to your computer and keep you } \\
\text { up with what's going on at a glance and not have } \\
\text { to spend a lot of time looking for web links? (CL) }\end{array}$ \\
\hline Intervening. & $\begin{array}{l}\text { Challenging comments made } \\
\text { by someone in a forum, using } \\
\text { a private channel (via IM). }\end{array}$ & $\begin{array}{l}\text { I saw she was on the I-chat, and I asked her, } \\
\text { "Why do you do that?" (Responding to a post } \\
\text { defending the use of clipart, a facilitator interrupts } \\
\text { via IM, prevailing on a teacher to change her } \\
\text { approach). }\end{array}$ \\
\hline
\end{tabular}




\section{About the Authors}

Jocelyn CRANEFIELD is Senior Lecturer in Information Systems and Director of the Master of Information Management Program at Victoria University's School of Business (Wellington, New Zealand). She has published in a number of peer-reviewed journals and conferences including ICIS, PACIS, HICCS, and ECIS. Jocelyn's research focuses on the role of online settings and social media in promoting organizational and professional change. Prior to completing her PhD in 2010, she held senior roles in the cultural and education sectors.

Pak YOONG is a Professor of Information Systems and was the foundation director of the PhD programme in the School of Information Management at the Victoria University of Wellington, New Zealand. His research, teaching and consulting experience is in the facilitation of virtual meetings, online communities of practice, online knowledge sharing, digital diplomacy and human resource development in information technology environments. He uses action learning and action research methods for many of his research projects and pioneered the use of "grounded action learning" method (a combination of grounded theory and action learning) in information systems research. His work has appeared in the Journal of Information Technology, DATABASE for Advances for Information Systems and Journal of Information Technology and People.

Sid HUFF is Professor Emeritus of Information Systems at Victoria University of Wellington, New Zealand and at the Ivey Business School in Canada. His teaching and research address IS strategy, IT governance and IS management. His work has appeared in numerous academic and practitioner journals, including MIS Quarterly, Information Systems Research, Journal of MIS, Journal of Strategic Information Systems, and Communications of the ACM. He has recently served as Senior Editor for Information Systems Management Journal and for Journal of Information Technology, and as Associate Editor for MIS Quarterly. He has also written over 60 teaching cases for educational use. He received his PhD in Information Systems from the MIT Sloan School of Management. 